Konya Mühendislik Bilimleri Dergisi, c. 9, s. 3, 766-786, 2021

Konya Journal of Engineering Sciences, v. 9, n. 3, 766-786, 2021

ISSN: 2667-8055 (Elektronik)

DOI: $10.36306 /$ konjes.915428

\title{
INVESTIGATION OF WIND ENERGY POTENTIAL OF FOUR DIFFERENT SITES OF LIBYA BY USING WEIBULL DISTRIBUTION
}

\section{Selcuk SELIMLI (iD) , ${ }^{2}$ Fauzi Ammar Ahmed SHTEWI ${ }^{(D)}$, ${ }^{3}$ Abdel Karim FAHED ${ }^{(D)}$, ${ }^{4}$ Çagıl Yaman KOYMATCIK (D) , ${ }^{5}$ Mehmet OZKAYMAK ${ }^{(D)}$}

\author{
Karabuk University, Energy Systems Engineering, Karabuk, TURKEY
}

1selcukselimli@karabuk.edu.tr,2f_shtewi68@yahoo.com,3fahedkazan82@gmail.com, 4kmcagil@gmail.com, 5mozkaymak@karabuk.edu.tr

(Geliş/Received: 14.04.2021; Kabul/Accepted in Revised Form: 12.09.2021)

\begin{abstract}
In this study wind energy capacity of Libyan sites are Espiaa, Msallata, Alqatrun, and Adirsiyah has been assessed with the Weibull distribution. Three different methods of Weibull distribution that are the Empirical Method of Justus (EMJ), the Graphical Method (GM), and the Maximum Likelihood Method (MLM) was used. As a result, the best velocity estimation performance has been obtained with graphical and maximum likelihood methods. The power density estimation showed that the wind power potential of Msallata is best with the value of $444.743 \mathrm{~W} / \mathrm{m}^{2}$ power density at $60 \mathrm{~m}$ and in Espiaa is in the second order with $414.98 \mathrm{~W} / \mathrm{m}^{2}$ potentials. Alqatrun is in the third order with the $184.134 \mathrm{~W} / \mathrm{m}^{2}$ power density and the last one is Adirsiyah with $101.201 \mathrm{~W} / \mathrm{m}^{2}$ potentials. When ordered for an elevation of $20 \mathrm{~m}$, the power density of Msallata was found $418.502 \mathrm{~W} / \mathrm{m}^{2}, 414.873 \mathrm{~W} / \mathrm{m}^{2}$ at Espiaa, $137.736 \mathrm{~W} / \mathrm{m}^{2}$ at Alqatrun, and $77.993 \mathrm{~W} / \mathrm{m}^{2}$ at Adirsiyah. The maximum power potential was determined at Msallata and the minimum at Adirsiyah. To investigate the most appropriate statistical method that provides the closest values to the real results, variance $\left(R^{2}\right)$, root mean square error (RMSE), mean bias error (MBE), and mean absolute error (MAE) values were calculated and assessed that at Adirsiyah, the best results were obtained with the GM method for a height of $20 \mathrm{~m}$. This situation was evaluated with a calculated maximum $\mathrm{R}^{2}$ of 0.9948 and minimum values of $0.0245,0.00037 \mathrm{RMSE}$, and MAE. For Espiaa, the GM method was determined as the most appropriate method with $0.9984 \mathrm{R}^{2}$, 0.0186 RMSE, 1.23e-06 MBE, and 0.00033 MAE values. For Msallata, the EMJ method was determined as the best method with $0.9985 \mathrm{R}^{2}, 0.0146 \mathrm{RMSE}, 2,4 \mathrm{e}-07 \mathrm{MBE}$, and $0.00022 \mathrm{MAE}$. For $60 \mathrm{~m}$ altitude, the EMJ method gave the most compatible results with 0.9957 $\mathrm{R}^{2}, 0.0221 \mathrm{RMSE}$, and 0.00027 MAE values in Adirsiyah. In Alqatrun, the MLM method provided the closest results with $0.9979 \mathrm{R}^{2}, 0.0151$ RMSE, 2.63e-06 MBE, and 0.00024 MAE. The MLM method for Espiaa was determined as the most suitable method with $0.9988 \mathrm{R}^{2}, 0.0163$ RMSE, 1.21e-06 MBE, and 0.00029 MAE. For Msallta, the EMJ method was determined as the most suitable method with $0.9986 \mathrm{R}^{2}, 0.0163 \mathrm{RMSE}, 1.83 \mathrm{e}-07 \mathrm{MBE}$, and 0.00019 MAE.
\end{abstract}

Keywords: Weibull distribution, wind speed, power density, wind energy.

\section{Libya'nın Dört Farklı Bölgesinin Rüzgâr Enerji Potansiyelinin Weibull Dağılımı ile İncelenmesi}

ÖZ: Bu çalışmada, Libyanın Espiaa, Msallata, Alqatrun ve Adirsiyah bölgesinin rüzgâr enerjisi kapasitesi Weibull dağılımı ile değerlendirilmiştir. Justus'un Ampirik Yöntemi (EMJ), Grafik Yöntemi (GM) ve Maksimum Olabilirlik Yöntemi (MLM) olmak üzere üç farklı Weibull dağılımı yöntemi kullanılmıştır. Sonuç olarak, en iyi hız tahmin performansı grafiksel ve maksimum olabilirlik yöntemleri ile elde edilmiştir. Güç yoğunluğu tahminlemesine göre Msallata'nın rüzgâr gücü potansiyelinin $60 \mathrm{~m}$ yükseklikte $444.743 \mathrm{~W} / \mathrm{m}^{2}$ güç yoğunluğu ile en iyi olduğu ve Espiaa'da ise $414.98 \mathrm{~W} / \mathrm{m}^{2}$ potansiyel ile ikinci sırada olduğunu görülmüştür. Alqatrun $184.134 \mathrm{~W} / \mathrm{m}^{2}$ güç yoğunluğu ile üçüncü sırada, sonuncu sırada ise $101.201 \mathrm{~W} / \mathrm{m}^{2}$ potansiyeli ile Adirsiyah belirlenmiştir. $20 \mathrm{~m}$ yükseklik için Msallata'nın güç 
yoğunluğu $418.502 \mathrm{~W} / \mathrm{m}^{2}$, Espiaa'da $414.873 \mathrm{~W} / \mathrm{m}^{2}$, Alqatrun'da $137.736 \mathrm{~W} / \mathrm{m}^{2}$ ve Adirsiyah'da 77.993 $\mathrm{W} / \mathrm{m}^{2}$ olarak belirlenmiştir. Maksimum güç potansiyeli Msallata'da, minimum ise Adirsiyah'da belirlenmiştir. Gerçek sonuçlara en yakın değerler sağlayan en uygun istatistiksel yöntemi belirlemek için varyans $\left(\mathrm{R}^{2}\right)$, kök ortalama kare hata (RMSE), ortalama sistematik hata (MBE) ve ortalama mutlak hata (MAE) değerleri hesaplanmış ve değerlendirilmiştir. Adirsiyah'ta $20 \mathrm{~m}$ yükseklik için en iyi sonuçlar GM yöntemi ile elde edilmiştir. Bu durum hesaplanan 0.9948 maksimum $\mathrm{R}^{2}$ ve minimum 0.0245, 0.00037 RMSE ve MAE değerleri ile değerlendirilmiştir. Alqatrun'da MLM yöntemi 0.9899 R², 0.0335 RMSE, 0.00049 MAE ile en uygun yöntem olarak ve en düşük karşılaştırma değeri olan 1.7e-5 MBE ile belirlenmiştir. Espiaa için GM yöntemi 0.9984 R$^{2}, 0.0186$ RMSE, 1.23e-06 MBE ve 0.00033 MAE değerleri ile en uygun yöntem olarak belirlendi. Msallata için EMJ yöntemi 0.9985 R², 0.0146 RMSE, 2,4e$07 \mathrm{MBE}$ ve $0.00022 \mathrm{MAE}$ değerleri ile en iyi yöntem olarak belirlendi.60 m yükseklik için Adirsiyah'ta EMJ yöntemi 0,9957 R², 0.0221 RMSE ve 0,00027 MAE değerleri ile en uyumlu sonuçları vermiştir. Alqatrun'da MLM yöntemi 0,9979 R², 0,0151 RMSE, 2,63e-06 MBE ve 0.00024 MAE değeri ile en yakın sonuçları sağlamıştır. Espiaa için MLM yöntemi 0,9988 R², 0,0163 RMSE, 1,21e-06 MBE ve 0,00029 MAE değeri ile en uygun yöntem olarak belirlenmiştir. Msallata için EMJ yöntemi 0,9986 R², 0,0163 RMSE, 1,83e-07 MBE ve 0,00019 MAE ile en uygun yöntem olarak belirlenmiştir.

Anahtar Kelimeler: Weibull dă̆glımı, rüzgâr hızı, güç yoğunluğu, rüzgâr enerjisi.

\section{INTRODUCTION}

Compared to fossil fuels that face the risk of depletion, wind energy is sustainable, environmentally friendly, and accessible in a wide geography. The development and improvement of communities are directly related to the sustainability of energy. In addition, due to the increased sensitivity to the environment, a global trend towards renewable energy resources is observed to a great extent. Libya has more than 48 billion barrels of oil reserves, or just under $3 \%$ of the world total, with a backupreplacement rate of 153 years [1]. By 2021, the Libyan national oil company produces only 1.22 million barrels a day on average but hopes to increase this to 2.1 million barrels per day by 2024 [2]. The natural gas proved reserve of the country is 51.3 billion cubic meters, it is estimated that the real reserve is approximately twice this amount with the unproven reserve [3]. The life and industrial activities of the country are carried out intensively with fossil fuel consumption. Fossil fuel-based national electricity consumption is about $33 \mathrm{TWh}$ per year and in 2020 wind-based part is $65 \mathrm{GWh}[4,5]$. According to the data of the United Nations, the population of Libya in 2020 is approximately 6,871,292 people, and the population growth rate has been approximately $2.2 \%$ since 1970 [6]. Libya from countries that live energy crisis is due to the dependence on only oil and gas energy [7]. With the increase in population, the need for electrical energy increases about $8-10 \%$ per year [8]. Approximately $65 \%$ of electricity demand in Libya is from thermal power plants that use petroleum-based fuels, and the rest use natural gas and petroleum by-products [9]. The emission value of $\mathrm{CO}_{2}$ emitted for electricity generation in Libya is $54 \%$ of the total emission and it is important that use renewable energy even only for emission reduction in Libya [10]. If oil-rich Libya wants to strengthen its oil-dependent economy in line with its future sustainability and environmental policies, it should also take steps in renewable energy and technologies. Especially in recent years, the civil war and destructions have significantly increased the need for energy and increased the importance of renewable energy applications. It is important to investigate the availability of wind and solar energy, especially in the country, $88 \%$ of which is desert [11]. Considering the African continent, Libya has significant potential with its annual wind capacity [12]. Libya has a $1900 \mathrm{~km}$ long coast where the wind speed does not fall below $5 \mathrm{~m} / \mathrm{s}$ [13]. The average wind power density varies from 164 to $426 \mathrm{~W} / \mathrm{m}^{2}$ in the country [14]. Renewable energies (wind, solar) take less than $1 \%$ of the energy supply of Libya and did not have a priority in energy politics until 2013 [15]. Problems erupting in Libya have hampered the plan to generate energy which is $10 \%$ of total electricity demand equivalent to 2,219 GW from renewable energy, until 2025[8]. Elmabruk et al. studied the wind energy and potential with Weibull distribution in some selected regions are Derna, 
Musrata, Zuara, and Sebha of Libya. They concluded that the mean annual wind speeds over $7.8 \mathrm{~m} / \mathrm{s}$ at Derna and has a higher energy capacity than other regions [16]. Hasan et al. evaluated the annual performance of the wind resource at the Zawiya region in the northwest of Libya with Weibull distribution [17]. Kassem et al. used Weibull distribution function to analyze the characteristics of wind speed in Libya. They assessed that the annual mean wind speed for the three regions considered in this study is ranging from 2.1 to $4.1 \mathrm{~m} / \mathrm{s}$ at $10 \mathrm{~m}$, which indicates that the investigated regions have low wind energy potential [18]. Elmabrouk investigated the wind energy potential of some of the Libyan sites by using Weibull distribution method. He concluded that Misurata has maximum energy potential with an annual average wind speed is over $4.88 \mathrm{~m} / \mathrm{s}$ [19]. Ali et al. provided a comparative evaluation of six methods for computing the Weibull parameters for Al-Aziziyah city of Libya. They argued that the statistical techniques that have been studied can help evaluate the Weibull distribution parameters for the measured data as the RMSE, Chisquare, and $\mathrm{R}^{2}$ values have similar magnitudes [20]. Elfarra and Silini studied on four selected different location near to the Libyan coast to do technical and economical evaluation of wind energy capacity by using real data with Weibull distribution. They suggested that use of Weibull parameters has remarkable effects on the evaluation of wind energy production [21]. Katsigiannis et al. examined the impact of the type of wind turbine classes on the wind sources electricity production in two regions of Cyprus Island. Resultantly presented that the superiority of design of wind turbines for lower wind speeds IEC III class in terms of power production [22]. AlNassar et al. determined the wind profile of different locations in the site of Kuwait with Weibull distribution. Maximum power density is observed at $30 \mathrm{~m}$ elevation is between 130 to $275 \mathrm{~W} / \mathrm{m}^{2}$ [23]. Mostafaeipour et al. studied the case and wind energy potential in Iran with Weibull distribution. Annual average value of wind power density is asserted approximately $110.6 \mathrm{~W} / \mathrm{m}^{2}$, wind power class of the state is determined 2 [24]. Ko et al. assessed the wind energy potential of Chuuk State, Micronesia.Wind energy density of Chuuk State was determined about $157.08 \mathrm{~W} / \mathrm{m}^{2}$ [25]. Irwanto et al. presented the wind speed profile estimation of Chuping and Kangar in Perlis, Malaysia. They discussed due to the Weibull distribution analyses that speed and probability of the wind is calculated approximately $0.97 \mathrm{~m} / \mathrm{s}$ and $73 \%$ in Chuping, and in Kangar are $2.5 \mathrm{~m} / \mathrm{s}$ and $45 \%$ [26]. Ahwide et al. concerned with the available wind energy data to investigate the electricity production in Libya. They concluded that yield of energy can be gained by the primary level of specific rate of energy is approximately of $820 \mathrm{~W} / \mathrm{m}^{2}$ [27]. Kassem et al. presented the analyze of wind speed characteristics of Libya's eastern Mediterranean coast. The results showed that the annual speed of wind and power density of it are $4.35 \mathrm{~m} / \mathrm{s}$ and $50.90 \mathrm{~W} / \mathrm{m}^{2}$ [28]. Mrehel et al. attempted to investigate the capacity of wind power in Libyan's southern state. The annual power density ranges among to $409.7 \mathrm{~W} / \mathrm{m}^{2}$ at Hun site and $693 \mathrm{~W} / \mathrm{m}^{2}$ at Alqatrun [5]. With the study, it is aimed to raise awareness about the importance of the tendency to renewable energy sources and the geographical potential in countries such as Libya, which have intensive fossil fuel based production and life. While statistical data are presented in many studies in the literature, whereas in this study statistical data were supported by comparing with real data, and different methods of Weibull distribution results were compared. In this study, technical assessment of the wind energy potential for four different sites, where are Msallata, Espiaa, Adirsiyah and Alqatrun of Libya. Adirsiyah is in the eastern coast and other two states are Espiaa and Msallata in the western coast and Alqatrun is in south. Three separate approaches, that are EMJ, GM and MLM methods of Weibull distribution were used in the determination of Weibull parameters. The Weibull distribution data that are determined by each method has been compared with the real data. Error analysis were done by calculation of $\mathrm{R}^{2}$, RMSE, MBE and MAE and by checking for the validity. The impacts of alternative Weibull parameters on the calculation results are also addressed. Wind energy potential of states are also identified and presented in this study. Assessment of wind power capability of four different Libyan sites are Msallata, Espiaa, Adirsiyah and Alqatrun has been done with taken annual wind data from Libyan National Meteorological Center. 


\section{METHODOLOGY}

\subsection{Wind Speed Estimation}

Wind power potential assessment requires wind speed determination. The obstacle on the ground surface and the surface roughness creates shear stress that suppresses wind speed, this stress zone formed between the earth's surface and approximately $5 \mathrm{~km}$ above of it is defined as the layer of atmospheric boundary. A logarithmic determination as seen in Eq. (1) or alternative power law as seen in Eq. (2) is a good method for determining the wind speed for the region [29, 30].

$\frac{v}{v_{o}}=\frac{\ln \frac{h}{z}}{\ln \frac{h_{0}}{z}}$

$\frac{v}{v_{o}}=\left(\frac{h}{h_{o}}\right)^{\alpha}$

Where $v_{o}$ is the reference wind speed at a height $h_{o}, v$ is the wind speed at height $h, \propto$ is the shear exponent which depends on the roughness of the terrain and $\mathrm{z}$ is the roughness length. The roughness length and shear exponent that is dependent on the characteristics of the terrain is given in Table 1.

Table 1. Surface-related parameters of the terrain.

\begin{tabular}{|c|c|c|c|}
\hline Type of terrain & $\begin{array}{c}\text { Roughness } \\
\text { class }\end{array}$ & $\begin{array}{c}\text { Roughness length } z \\
(\mathrm{~m})\end{array}$ & $\begin{array}{c}\text { Shear exponent } \\
(\propto)\end{array}$ \\
\hline Water area & 0 & 0.001 & 0.01 \\
\hline $\begin{array}{c}\text { Nation clear, few surface } \\
\text { characteristics }\end{array}$ & 1 & 0.12 & 0.12 \\
\hline $\begin{array}{c}\text { Agriculture of hedges and } \\
\text { houses }\end{array}$ & 2 & 0.05 & 0.16 \\
\hline $\begin{array}{c}\text { Agriculture of multiple } \\
\text { crops, woods, and villages }\end{array}$ & 3 & 0.3 & 0.28 \\
\hline
\end{tabular}

Wind data were analyzed for heights of $20 \mathrm{~m}$ and $60 \mathrm{~m}$ using three different parametric value determination types of the Weibull distribution method.

\subsection{Determination of Weibull Distribution Parameters by Different Methods}

Weibull distribution method can be applied with different alternative parameterizations for different disciplinary problems [31]. In this study, EMJ, GM, and MLM are used to determine the parameters. The parametric form of probability density and cumulative distribution functions of Weibull distribution is expressed in Eq. (3) and Eq. (4) [32].

$F(v)=\left(\frac{k}{c}\right)\left(\frac{v}{c}\right)^{k-1} \exp \left[-\left(\frac{v}{c}\right)^{k}\right] \quad(k>0, v>0, c>1)$
$F(v)=1-\exp \left[-\left(\frac{v}{c}\right)^{k}\right]$

$F(v)$ is the probability of wind speed, $k$ is the dimensionless shape parameter, and $c$ is the scale parameter $(\mathrm{m} / \mathrm{s})$. The relations that give the Weibull distribution parameters according to the EMJ are given in Eq. (5) and Eq. (6) [33].

$k=\left(\frac{v_{m}}{\sigma}\right)^{-1.086}$ 
$c=\frac{v_{m}}{\Gamma\left(1+\frac{1}{k}\right)}$

In the relations $v_{m}$ presents mean wind speed $(\mathrm{m} / \mathrm{s})$ and can be equated as in Eq. (7), $\sigma$ is the standard deviation of wind speed, $\Gamma$ is the gamma function and is defined as in Eq. (8) [34, 35].

$\mathrm{V}_{\mathrm{m}}=\frac{1}{\mathrm{n}} \sum_{i=1}^{\mathrm{n}} v_{i}$

$\Gamma(\mathrm{t})=\int_{0}^{\infty} e^{-x} x^{t-1} d x$

Where; $n$ is the number of observations. The standard deviation of wind speed is defined with the relation is seen in Eq. (9) [36].

$\left[\frac{1}{n-1} \sum_{i=1}^{n}\left(v_{i}-v_{m}\right)^{2}\right]^{0.5}$

Equations give the parameters of the Weibull distribution according to the GM is presented in Eq. (10) [37].

$\ln [-\ln (1-F(v))]=k \ln v-k \ln c$

Firstly, by using wind speed data, the cumulative frequency distribution is calculated, then by using the frequency distribution, the cumulative frequency distribution can be obtained. Then, pairs are lnv and $\ln [-\ln (1-F(v))]$ be solved. Lastly, shape and scale parameters are found by solving linear least squares relation. The parameters are related as in Eq. (11) and Eq. (12) [38].

$k=a$

$c=e^{-\frac{b}{a}}$

Weibull distribution parameters can be determined with the functions are seen in Eq. (13) and Eq. (14) according to the MLM [39].

$k=\left[\frac{\sum_{i=1}^{n} v_{i}^{k} \ln v_{i}}{\sum_{i=1}^{n} v_{i}^{k}}-\frac{1}{n} \sum_{i=1}^{n} \ln v_{i}\right]^{-1}$

$c=\left[\frac{1}{n} \sum_{i=1}^{n} v_{i}^{k}\right]^{\frac{1}{k}}$

\subsection{Statistical Error Analyses}

The accuracy of applied methods is investigated by some statistical approximations that are the determination of variance $\left(R^{2}\right)$ in Eq. (15), the root means square error (RMSE) in Eq. (16), mean bias error (MBE) in Eq. (17), and mean absolute error (MAE) in Eq. (18) [35, 40].

$$
\begin{aligned}
& R^{2}=\frac{\left(\sum_{i=1}^{n}\left(y_{i}-z_{i}\right)^{2}-\sum_{i=1}^{n}\left(y_{i}-x_{i}\right)^{2}\right)}{\sum_{i=1}^{n}\left(y_{i}-z_{i}\right)^{2}} \\
& R M S E=\sqrt{\frac{1}{n} \sum_{i=n}^{n}\left(y_{i}-x_{i}\right)^{2}} \\
& M B E=\frac{1}{n} \sum_{i=1}^{n}\left(y_{i}-x_{i}\right) \\
& M A E=\frac{1}{n} \sum_{i=1}^{n}\left|y_{i}-x_{i}\right|
\end{aligned}
$$

$x_{i}, y_{i}$ and $z_{i}$ present predicted $i^{t h}$ wind speed, $i^{\text {th }}$ wind speed of real data and average wind speed. 


\subsection{Wind Power Density}

Wind power density (WPD) is calculated to determine the wind energy potential with the formula is seen in Eq. (19) [41].

$W P D=\frac{1}{2} \rho v_{h}^{3}$

$\rho$ is the air density, and $v_{h}$ is the wind speed at hub elevation.

The wind turbine power production $(P)$ can be calculated with Eq. (20) [29].

$P=\frac{1}{2} \rho C_{p} A_{t} v_{h}^{3}$

$P$ represents the power, $C_{p}$ designates the turbine capacity parameter, $A_{t}$ swept sectional area of the turbine.

\section{CASE STUDY}

In this study, it has been tried to determine the wind energy potential for the Msallata, Espiaa, Alqatrun, and Adirsiyah sites in Libya by using monthly average wind speed data for a year were obtained for $20 \mathrm{~m}$ and $60 \mathrm{~m}$ altitudes to evaluate medium and upper altitude from the Libyan National Meteorological Agency and evaluated within the scope of the study.

\subsection{Site Location and Wind Speed Data}

The locations of four Libyan sites are Msallata, Espiaa, Adir Siyah, and Alqatrun, locations and wind potential are presented in Fig. 1.

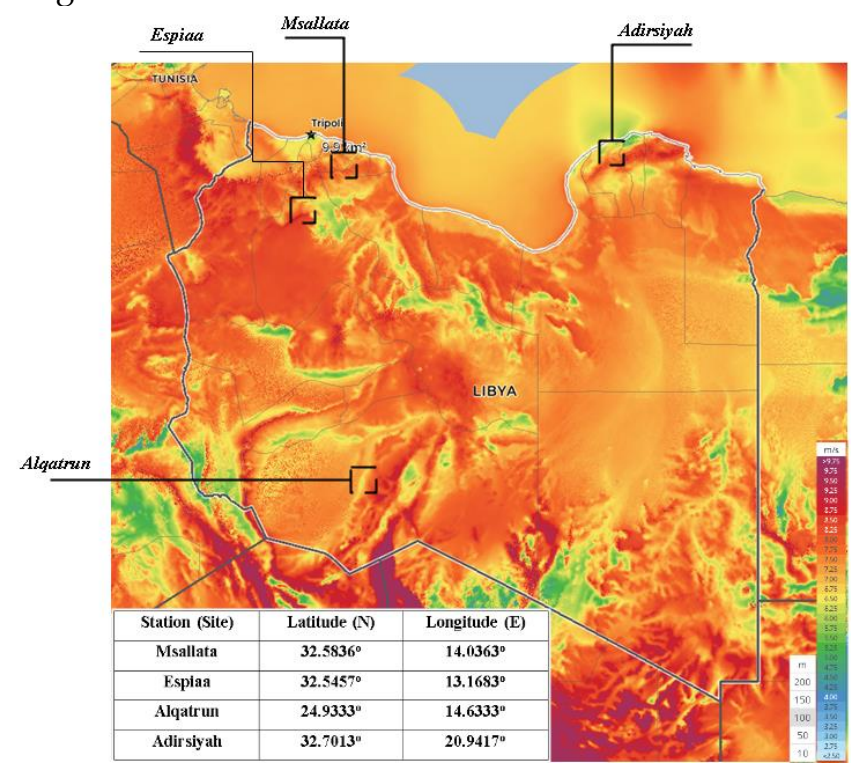

Figure. 1. Geographic location and wind map of studied states.

Msallata and Espiaa are in the northwest of Libya. Adirsiyah is in the northeast and Alqatrun is in the southwest of the country. Altitude above sea level and estimated atmospheric air pressure and density from thermodynamic tables [42] and relative humidity data are taken from Libyan National Meteorological Agency for Msallata, Espiaa, Adir Siyah, and Alqatrun are given in Table 2. 
Table 2. Altitude of four state and atmospheric air properties.

\begin{tabular}{|l|c|c|c|c|}
\hline Station (Site) & Altitude $(\mathrm{m})$ & Pressure $(\mathrm{kPa})$ & Density $\left(\mathrm{kg} / \mathrm{m}^{3}\right)$ & Relative humidity (\%) \\
\hline Msallata & $198 \mathrm{~m}$ & 98.97 & 1.202 & 58 \\
\hline Espiaa & $156 \mathrm{~m}$ & 99.47 & 1.207 & 55 \\
\hline Alqatrun & $518 \mathrm{~m}$ & 95.26 & 1.165 & 43 \\
\hline Adirsiyah & $332 \mathrm{~m}$ & 97.40 & 1.186 & 70 \\
\hline
\end{tabular}

Local wind speed and power values were evaluated for heights of 20 and $60 \mathrm{~m}$ from the ground. The surface characteristics related to parameters of the terrain are evaluated due to Table 1 . When the data presented in Fig. 2 (a, b), in which wind regimes are visualized monthly for 20 and 60 m altitudes, are examined, a monthly evaluation of the maximum and minimum wind potentials for each location can be made for a year.

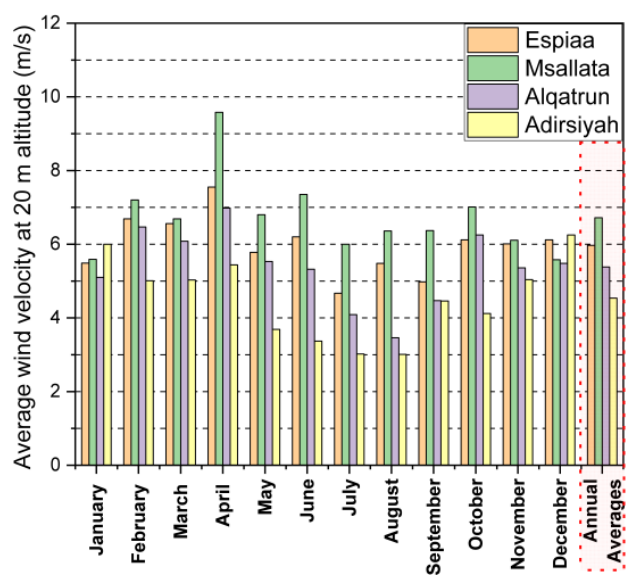

(a)

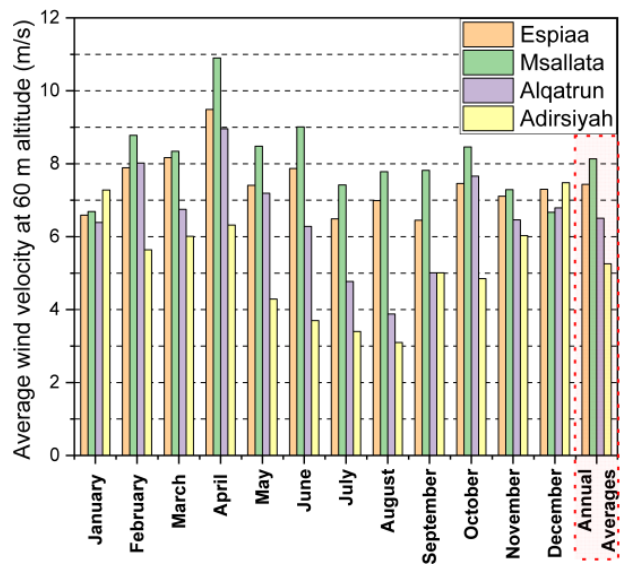

(b)

Figure. 2. Monthly average wind speeds at a) $20 \mathrm{~m}$ and b) $60 \mathrm{~m}$.

When the values are given for $20 \mathrm{~m}$ height in Fig. 2(a) are examined, the maximum wind speed values for Espiaa, Msallata, and Alqatrun are 7.55, 9.58, and $6.98 \mathrm{~m} / \mathrm{s}$ in April, respectively, while for Adirsiyah it is $6.25 \mathrm{~m} / \mathrm{s}$. The maximum value of speed is seen in December for Adirsiyah. Minimum wind speed values were determined as 4.67, 5.58, 3.46, $3.01 \mathrm{~m} / \mathrm{s}$, respectively, in Espiaa in July, in Msallata in November, and in Alqatrun and Adirsiyah in August. When the annual average values are examined, for a height of $20 \mathrm{~m}$, Msallata has $6.72 \mathrm{~m} / \mathrm{s}$, Espiaa $5.97 \mathrm{~m} / \mathrm{s}$, Alqatrun 5.38, and Adirsiyah 4.53 $\mathrm{m} / \mathrm{s}$ wind speed values. As seen in Figure 2(b), the maximum wind speed was determined at $60 \mathrm{~m}$ high in April for Espiaa, Msallata, and Alqatrun with values are 9.49, 10.9, and $8.96 \mathrm{~m} / \mathrm{s}$, and $7.48 \mathrm{~m} / \mathrm{s}$ in December for Adirsiyah. Minimum wind speed was determined in September for Espiaa, in December for Msallata, and in August for Alqatrun and Adirsiyah with values are 6.45, 6.66, 3.88, and $3.1 \mathrm{~m} / \mathrm{s}$. The annual average wind speed values for Espiaa, Msallata, Alqatrun, and Adirsiyah are 7.43, 8.13, 6.5, and $5.25 \mathrm{~m} / \mathrm{s}$. Oner et al. assessed that the fields where the wind speed values are over $5 \mathrm{~m} / \mathrm{s}$ can be seen as suitable for a wind farm [43]. In this respect, entire sites have wind power production capacity, but the most feasible one is Msallata.

\section{RESULTS AND DISCUSSION}

The annual average wind speed frequency curves are plotted for all the sites in Fig. 3 for a) $20 \mathrm{~m}$ and b) 60 m elevation. 


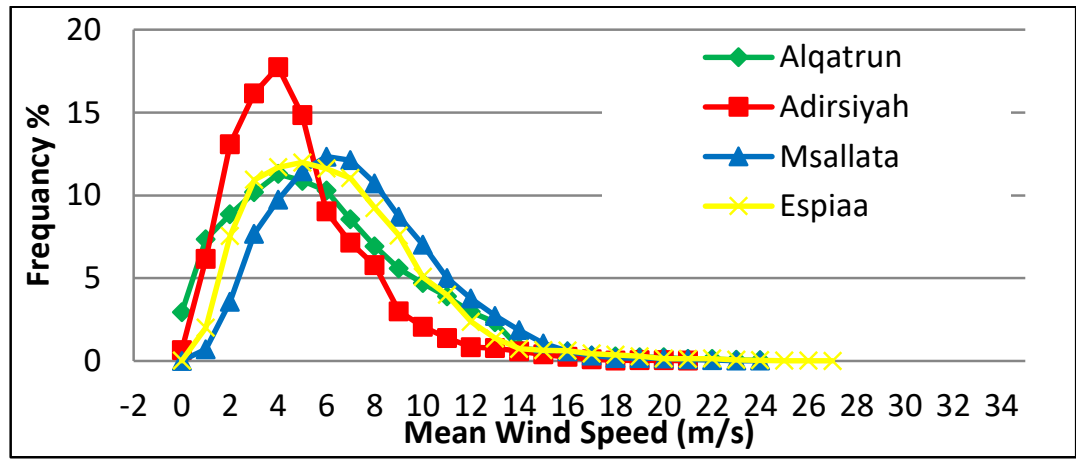

(a)

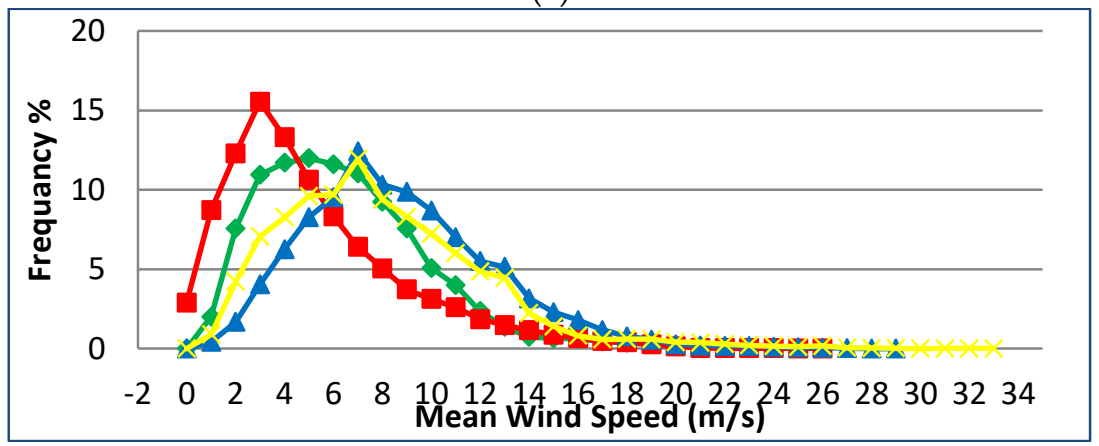

(b)

Figure 3. Measured annual frequency distribution at a) $20 \mathrm{~m}$, b) $60 \mathrm{~m}$.

In Alqatrun, the wind at an altitude of $20 \mathrm{~m}$ has a speed of $5 \mathrm{~m} / \mathrm{s}$ at a rate of $10.87 \%$. This rate was determined as $14.83 \%$ in Adirsiyah, $11.46 \%$ in Msallata, and $11.98 \%$ in Espiaa. The wind has a speed value of $6 \mathrm{~m} / \mathrm{s}$ at a rate of $10.28 \%$ in Alqatrun. This rate is $9 \%$ in Adirsiyah, 12.34\% in Msallata, and $11.61 \%$ in Espiaa. When the energy producibility was evaluated in terms of consistency, Msallata, Espiaa, Alqatrun, and Adirsiyah rankings were evaluated numerically. The maximum frequency value was determined at $12.34 \%$ for $6 \mathrm{~m} / \mathrm{s}$ wind speed in Msalata, with $11.98 \%$ for $5 \mathrm{~m} / \mathrm{s}$ in Espiaa, $17.75 \%$, and $11.29 \%$ for $4 \mathrm{~m} / \mathrm{s}$ in Adir Siyah and Alqatrun. At $60 \mathrm{~m}$ altitude, $5 \mathrm{~m} / \mathrm{s}$ wind speed is $11.98 \%$ in Alqatrun, $10.63 \%$ in Adirsiyah, $8.28 \%$ in Msallata and $9.62 \%$ in Espiaa. For $6 \mathrm{~m} / \mathrm{s}$ wind speed in the same order is $11.61 \%, 8.33 \%, 9.52 \%$, and $9.67 \%$. The productibility of the energy was evaluated in terms of consistency, and the ranking of Msallata, Espiaa, Alqatrun, and Adirsiyah was evaluated numerically. The peak frequency value was determined at $12.40 \%$ and $11.94 \%$ for $7 \mathrm{~m} / \mathrm{s}$ wind speed in Msalata and Espiaa, while $11.98 \%$ for $5 \mathrm{~m} / \mathrm{s}$ in Alqatrun, $15.54 \%$ for $3 \mathrm{~m} / \mathrm{s}$ in Adirsiyah. The Weibull parameters were calculated using the three different methods that are, EMJ, GM, and MLM. The results corresponding to the GM related with the log-linear regression for each site are shown in Fig. 4(a, b, c, d) for $20 \mathrm{~m}$ elevation and Fig. 5(a, b, c, d) for 60 m elevation. 


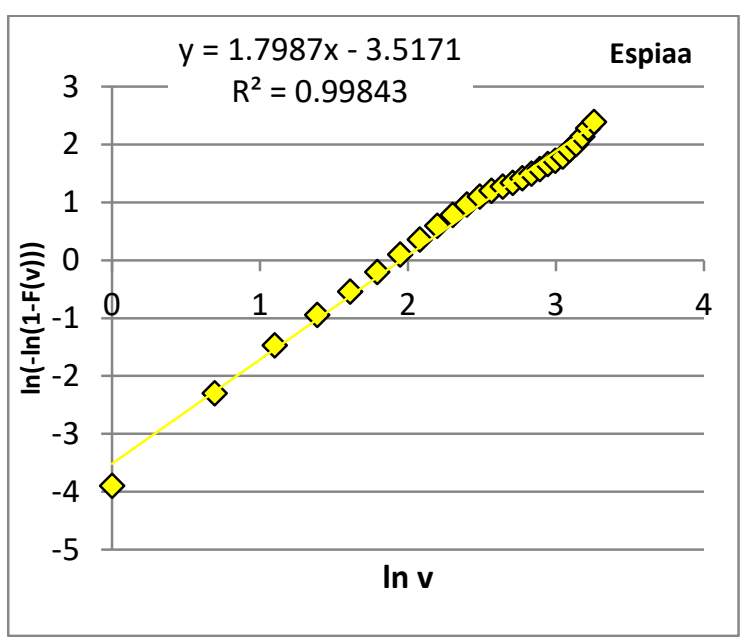

a)

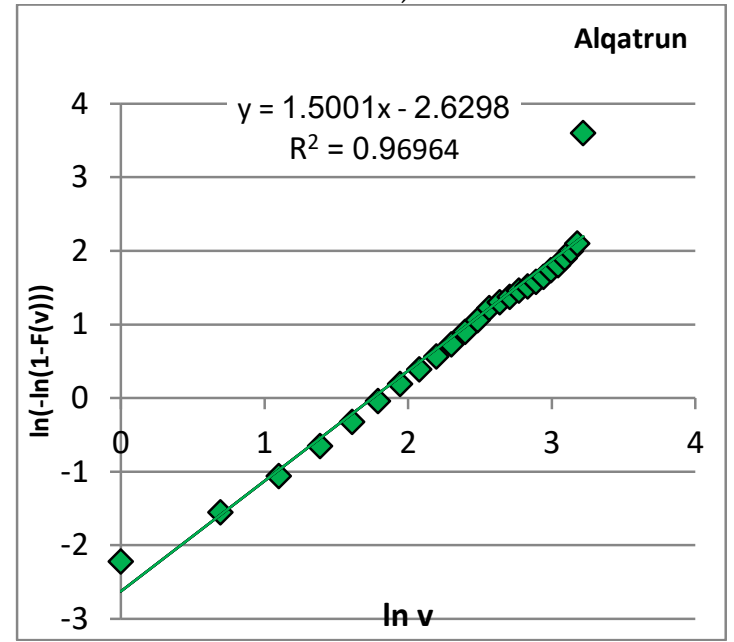

(c)

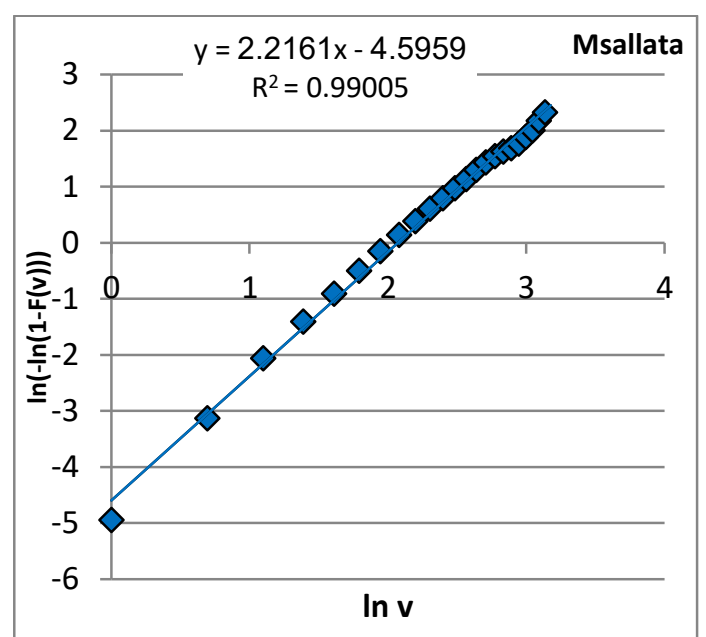

(b)

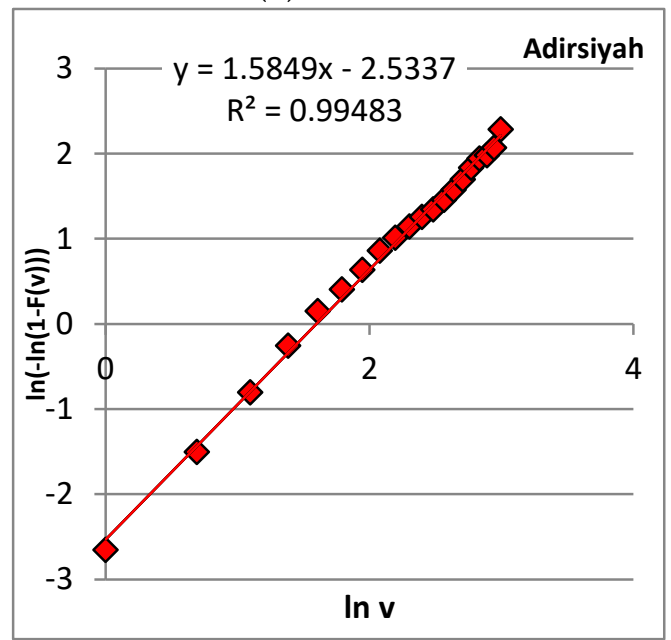

(d)

Figure 4. (a, b, c, d) GM to estimate the Weibull parameters at 20m. 


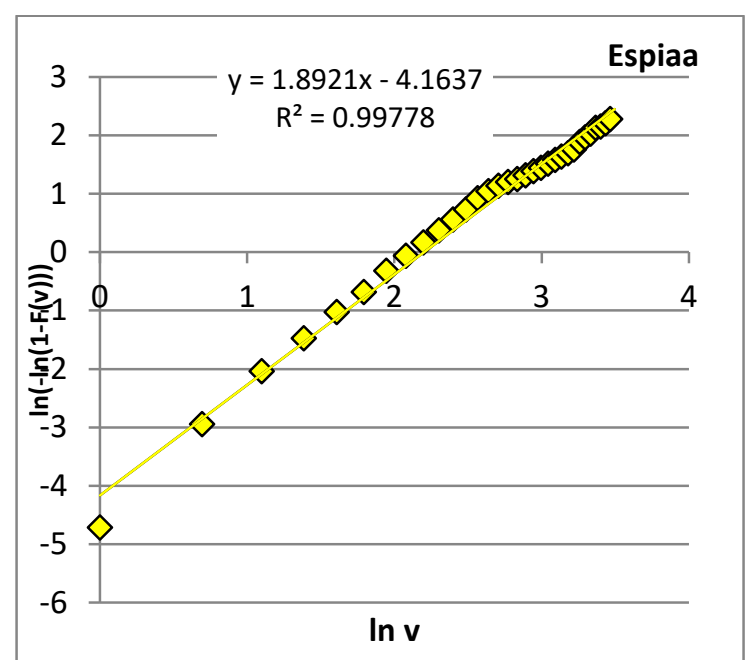

(a)

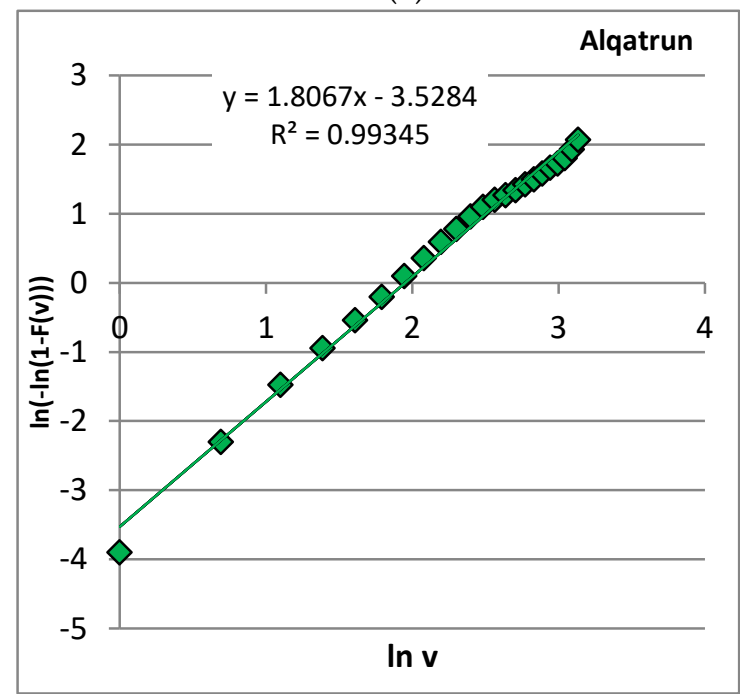

(c)

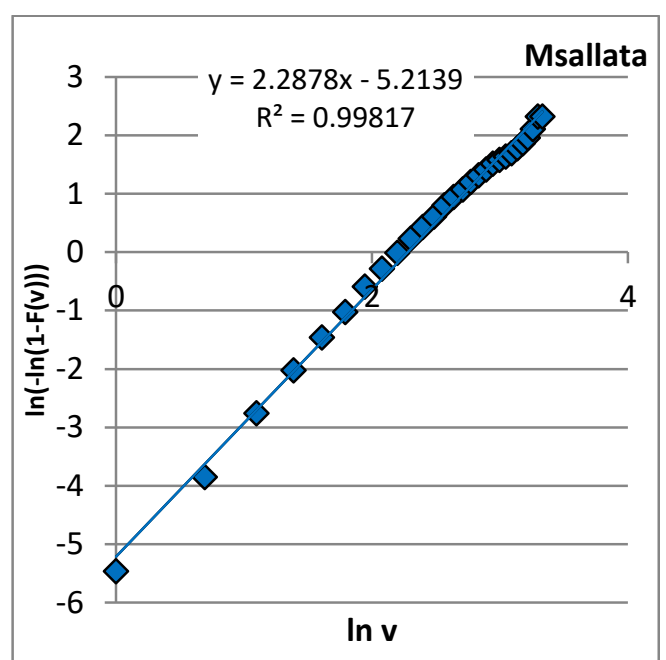

(b)

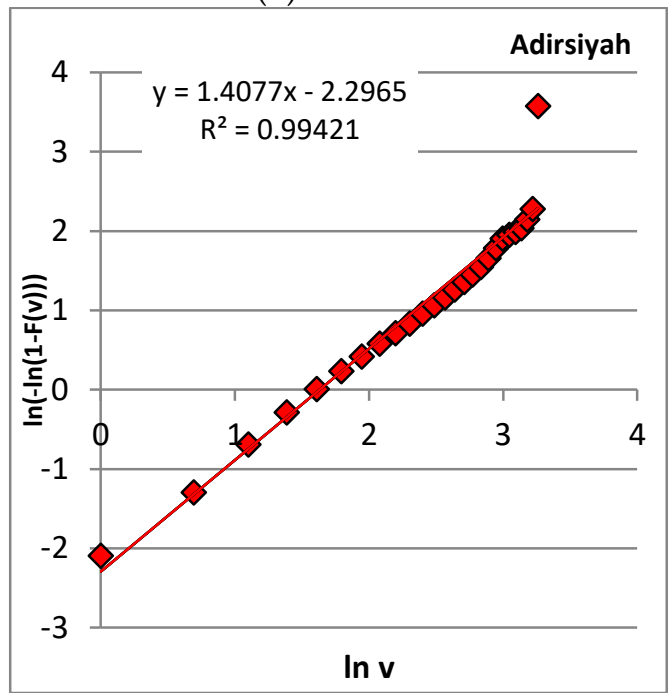

(d)

Figure 5. (a, b, c, d) GM to estimate the Weibull parameters at $60 \mathrm{~m}$.

Determination of Weibull parameters that are shape parameter (k) and scale parameter (c) is necessary. The scale parameter can be related to the mean wind speed and the shape factor, which determines the consistency of wind speed at a given location [44]. The determined parameters with three different methods were given in Table 3 and Table 4 for $20 \mathrm{~m}$ and $60 \mathrm{~m}$ elevations.

Table 3. Weibull Parameters are estimated by three different methods for $20 \mathrm{~m}$ elevations.

\begin{tabular}{|c|c|c|c|c|c|c|}
\hline \multirow{3}{*}{ Site } & \multicolumn{6}{|c|}{ Methods } \\
\cline { 2 - 7 } & \multicolumn{2}{|c|}{ GM } & \multicolumn{2}{c|}{ EMJ } & \multicolumn{2}{c|}{ MLM } \\
\cline { 2 - 7 } & $k$ & $c$ & $k$ & $c$ & $k$ & $c$ \\
\hline Msallata & $\mathbf{2 . 2 1 6 1}$ & $\mathbf{7 . 9 5 6 2}$ & 2.341 & 8.172 & $\mathbf{2 . 5 5 2}$ & $\mathbf{8 . 3 4 4}$ \\
\hline Espiaa & $\mathbf{1 . 7 9 8 7}$ & $\mathbf{7 . 0 6 6 4}$ & 2.215 & 7.224 & $\mathbf{2 . 2 2 3}$ & $\mathbf{7 . 5 1 5}$ \\
\hline Alqatrun & $\mathbf{1 . 5 0 0 1}$ & $\mathbf{5 . 7 6 6 5}$ & 1.613 & 6.625 & $\mathbf{1 . 7 2 1}$ & $\mathbf{6 . 7 6 3}$ \\
\hline Adirsiyah & $\mathbf{1 . 5 8 4 9}$ & $\mathbf{4 . 9 4 8 1}$ & 1.672 & 5.076 & $\mathbf{2 . 0 9 4}$ & $\mathbf{5 . 6 3 4}$ \\
\hline
\end{tabular}


Table 4. Weibull Parameters were estimated by three different methods for $60 \mathrm{~m}$ elevations.

\begin{tabular}{|c|c|c|c|c|c|c|}
\hline \multirow{3}{*}{ Site } & \multicolumn{5}{|c|}{ Methods } \\
\cline { 2 - 8 } & \multicolumn{2}{|c|}{$\mathrm{GM}$} & \multicolumn{2}{c|}{ EMJ } & \multicolumn{2}{c|}{ MLM } \\
\cline { 2 - 8 } & $k$ & $c$ & $k$ & $c$ & $k$ & $c$ \\
\hline Msallata & $\mathbf{2 . 2 8 7 8}$ & $\mathbf{9 . 7 7 3 3}$ & 2.423 & 9.814 & $\mathbf{2 . 6 4 3}$ & $\mathbf{1 0 . 0 2 0}$ \\
\hline Espiaa & $\mathbf{1 . 8 9 2 1}$ & $\mathbf{9 . 0 2 9 8}$ & 2.045 & 9.024 & $\mathbf{2 . 2 9 0}$ & $\mathbf{9 . 1 8 5}$ \\
\hline Alqatrun & $\mathbf{1 . 8 0 6 7}$ & $\mathbf{7 . 0 5 3 3}$ & 1.981 & 7.282 & $\mathbf{2 . 2 1 4}$ & $\mathbf{7 . 4 9 1}$ \\
\hline Adirsiyah & $\mathbf{1 . 4 0 7 7}$ & $\mathbf{5 . 1 1 3 4}$ & 1.435 & 5.750 & $\mathbf{1 . 7 2 1}$ & $\mathbf{6 . 0 9 4}$ \\
\hline
\end{tabular}

When the value of shape parameter compared to four sites, it is seen that in Table 4 , the highest value of it was determined 2.643 for Msallata, 2.29 for Espiaa, 2.214 for Alqatrun, and 1.721 for Adirsiyah with MLM. The lowest values were determined as 2.2878 for Msallata, 1.8921 for Espiaa, 1.8067 for Alqatrun, and 1.4077 for Adirsiyah with GM. The highest value of $\mathrm{k}$ means the more stable wind blow at a state. MLM method gives a higher value for the $\mathrm{k}$ parameter in each studied site while the GM method gives the lowest value for the $\mathrm{k}$ parameter. Similarly, for $\mathrm{c}$ the maximum variation from mean wind speed has been determined with MLM and minimum with GM for each site and at two different elevations. By using the Weibull parameters, the probability density function and cumulative distribution function can be determined. The probability density function corresponds to the wind blow frequency. Calculated probability density function values with EMJ, GM, and MLM were fitted against the frequency of the actual wind data in Fig. 6(a, b, c, d) and Fig. 7(a, b, c, d). 


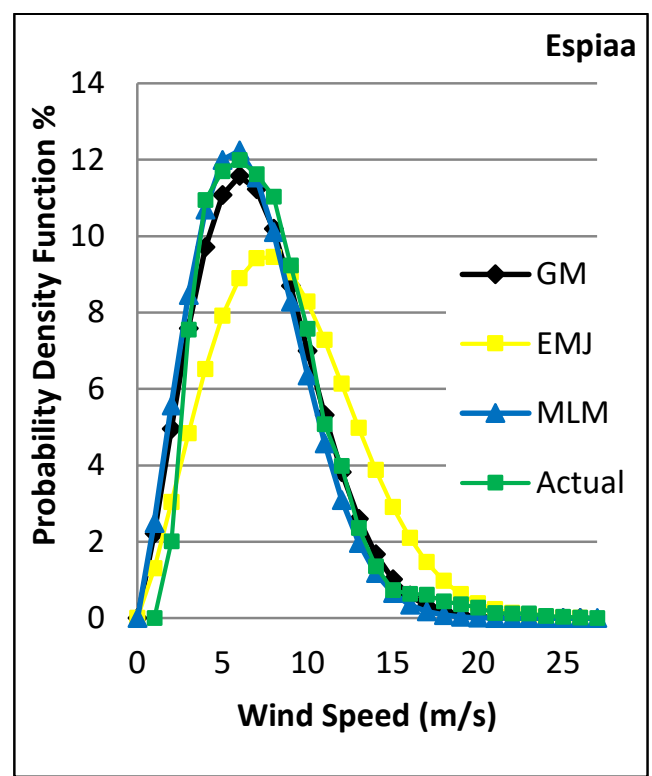

(a)

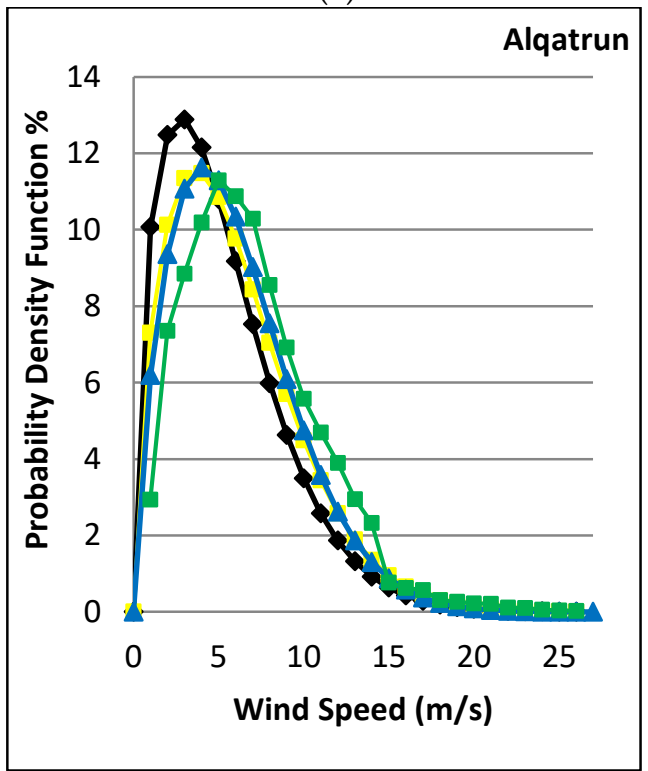

(c)

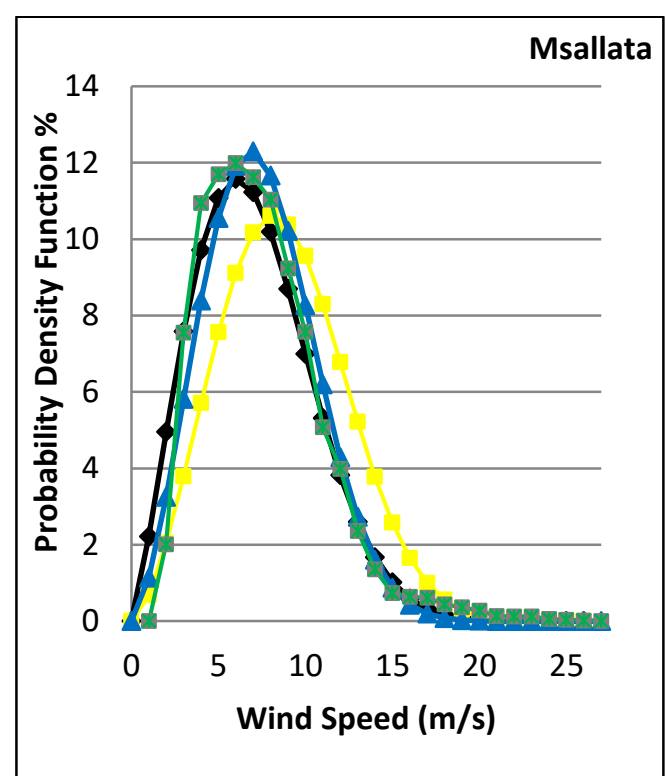

(b)

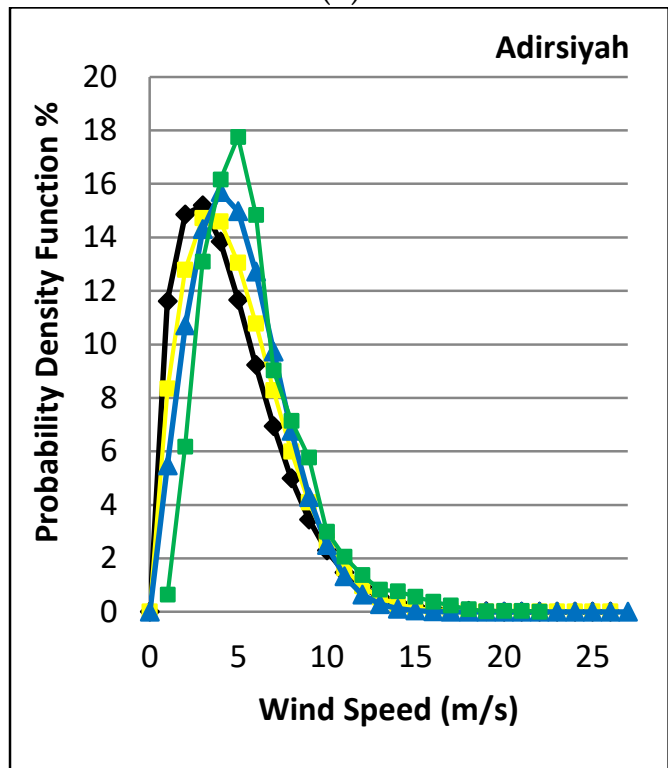

(d)

Figure 6. (a, b, c, d) Comparison of the probability density function at $20 \mathrm{~m}$. 


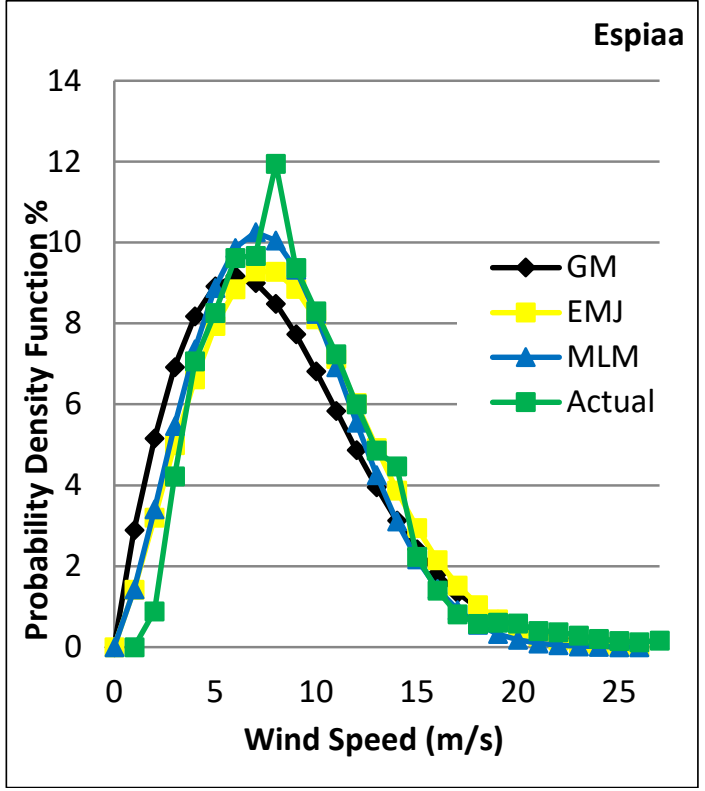

(a)

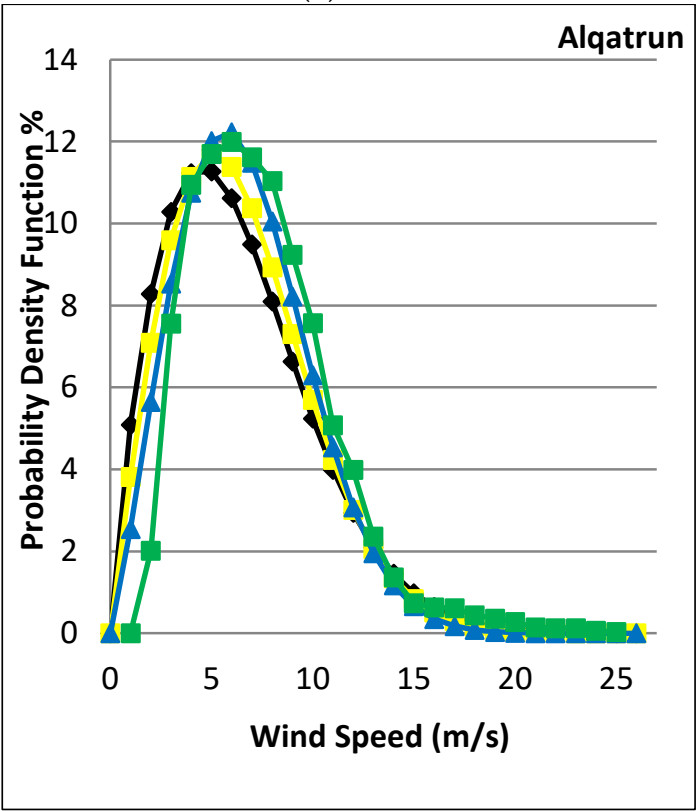

(c)

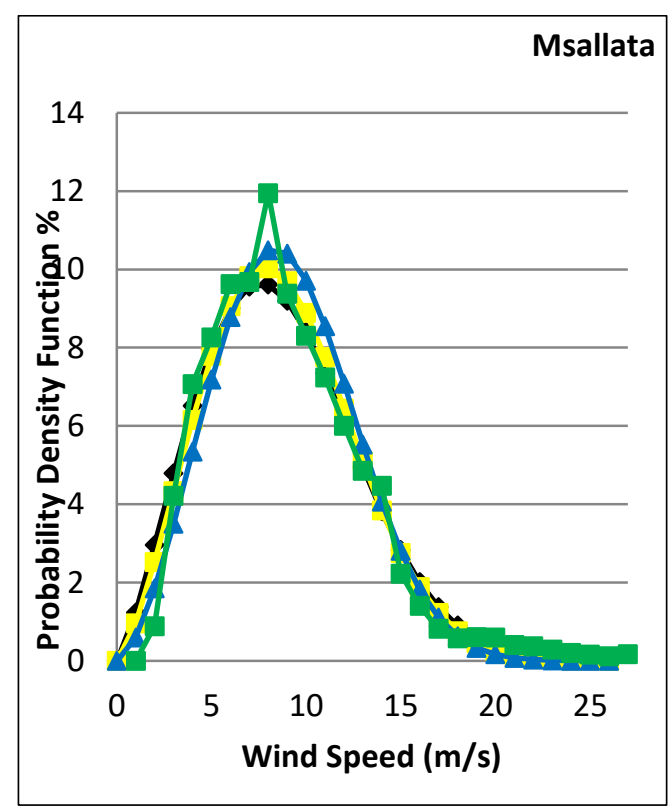

(b)

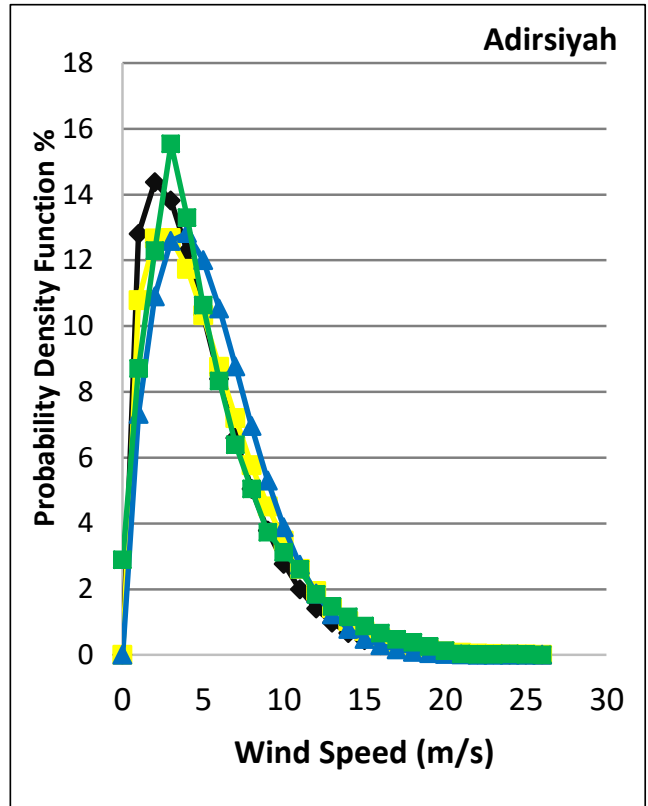

(d)

Figure 7. $(a, b, c, d)$ Comparison of the probability density function $60 \mathrm{~m}$.

Fig. 6(a, b, c, d) and Fig. 7(a, b, c, d) show that the estimated wind speed is lower than the actual at Adirsiyah and Alqatrun. At Espiaa and Msallata the estimated and actual data are overlapped well, and the higher wind speed values have a higher probability than other sites. According to the Fig. $6(\mathrm{a}, \mathrm{b}, \mathrm{c}, \mathrm{d})$ the most probable wind speed for Espiaa is $6 \mathrm{~m} / \mathrm{s}$ with $(11.57 \%$ probable), for Msallata is $8 \mathrm{~m} / \mathrm{s}$ with (10.6\% probable), for Alqatrun is $4 \mathrm{~m} / \mathrm{s}$ with (11.62\% probable), and for Adirsiyah is $3 \mathrm{~m} / \mathrm{s}$ with $(15.19 \%$ probable) at $20 \mathrm{~m}$ elevation. In the same order at $60 \mathrm{~m}$ elevation the values reach to $7 \mathrm{~m} / \mathrm{s}(10.25 \%$ probable), $8 \mathrm{~m} / \mathrm{s}(10.02 \%$ probable), $6 \mathrm{~m} / \mathrm{s}$ (12.22\% probable) and $3 \mathrm{~m} / \mathrm{s}$ (\%12.67 probable) as seen in Fig. $7(a, b, c, d)$. Evaluation of peak and tail fit of different methods showed that the best fitting was obtained with the MLM for each different site. The different methods of cumulative distribution function estimation are presented in Fig. 8(a, b, c, d) and Fig. 9(a, b, c, d) for $20 \mathrm{~m}$ and $60 \mathrm{~m}$ elevation data. 


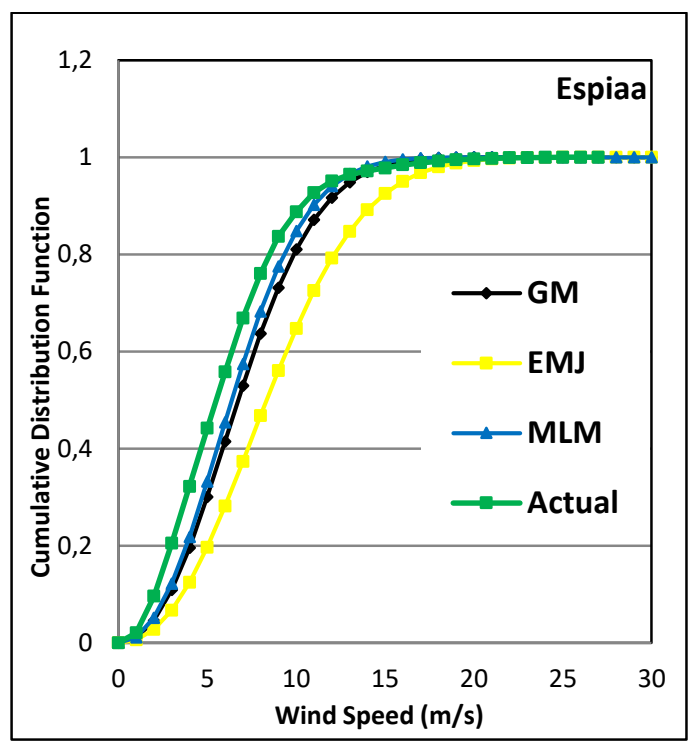

(a)

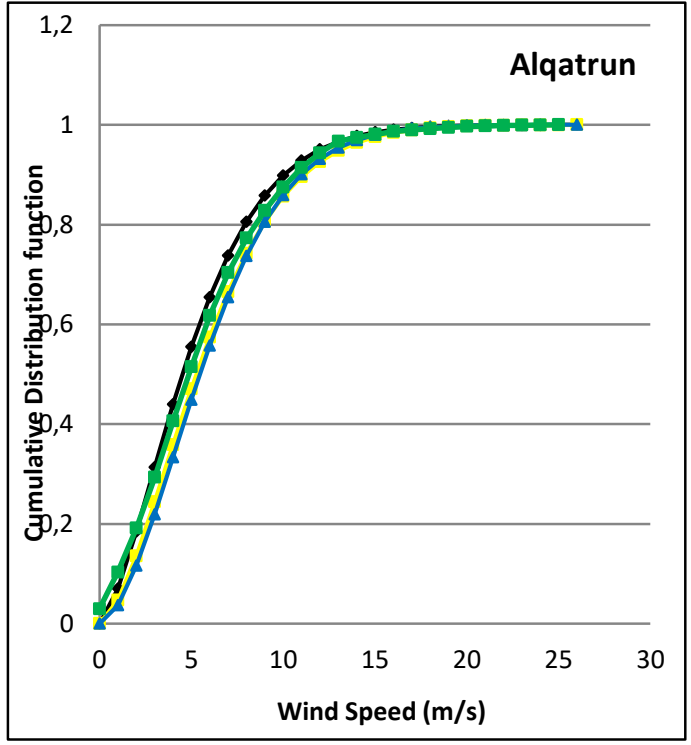

(c)

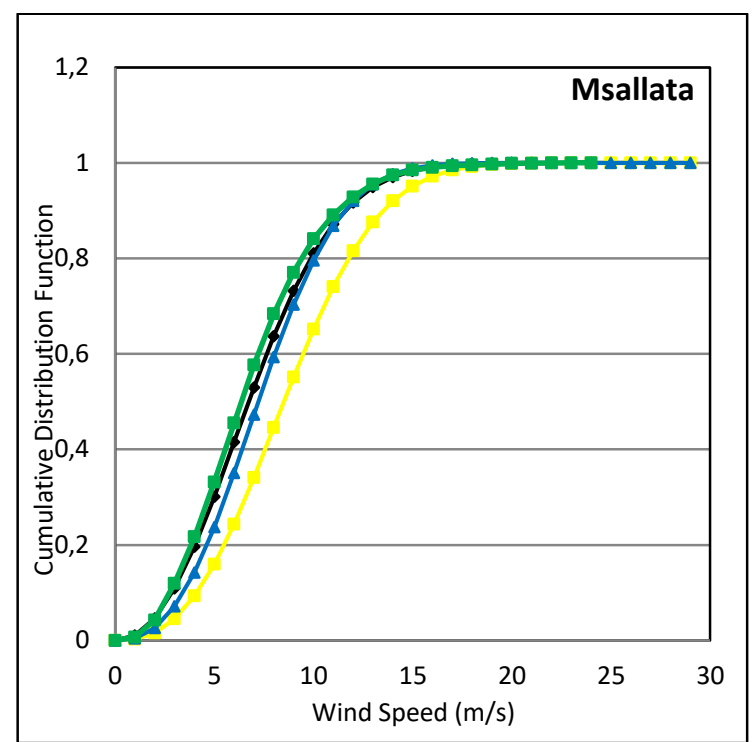

(b)

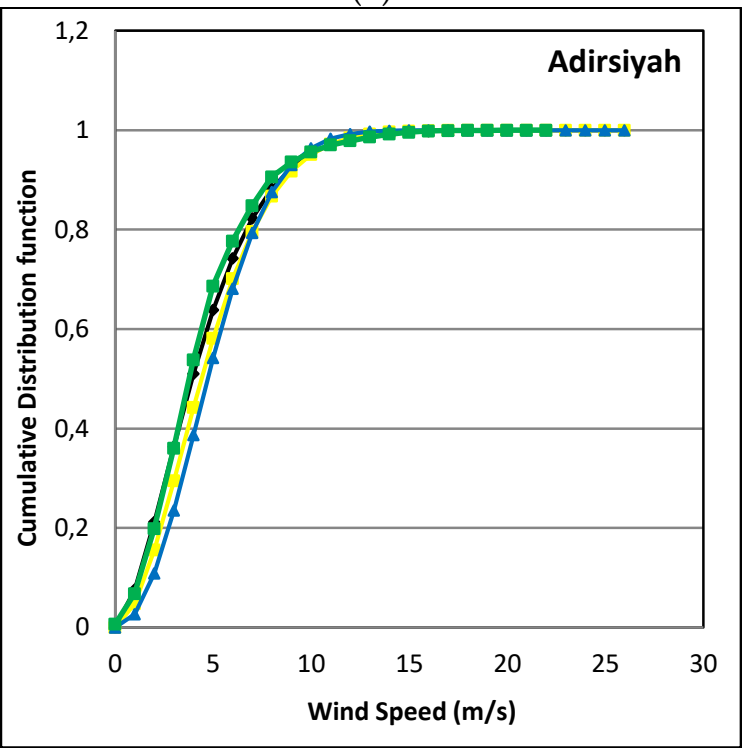

(d)

Figure 8. $(a, b, c, d)$. The cumulative distribution function for the sites at $20 \mathrm{~m}$ height. 


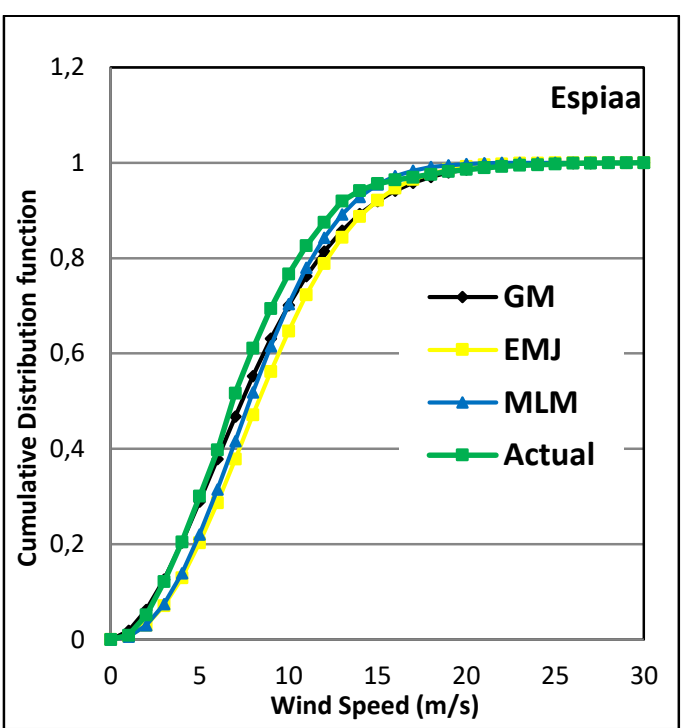

(a)

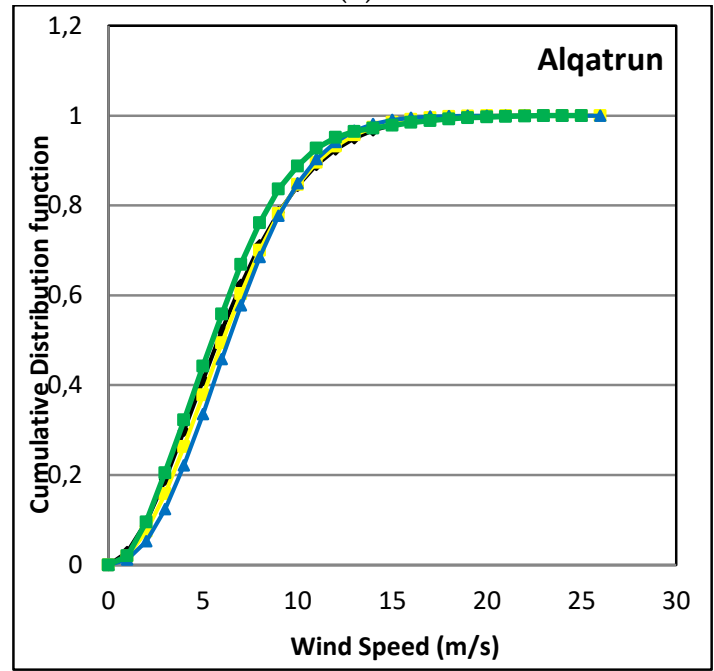

(c)

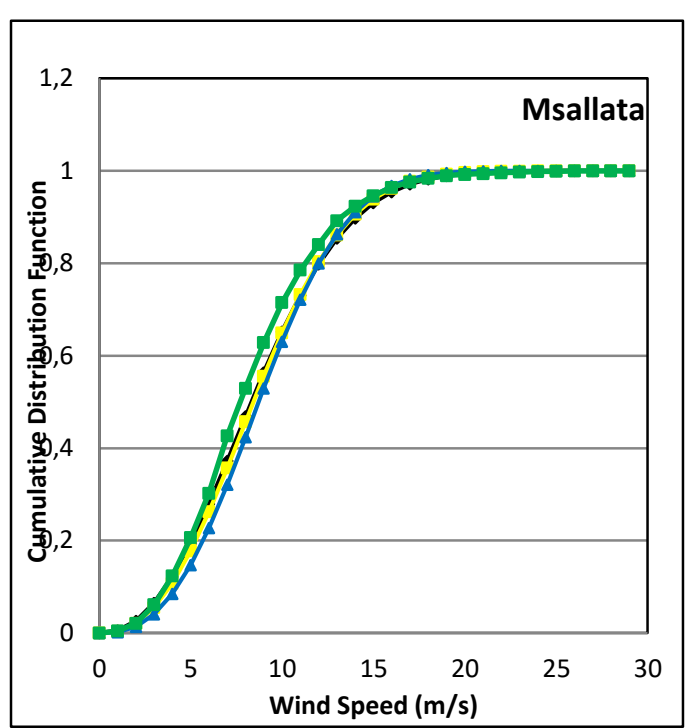

(b)

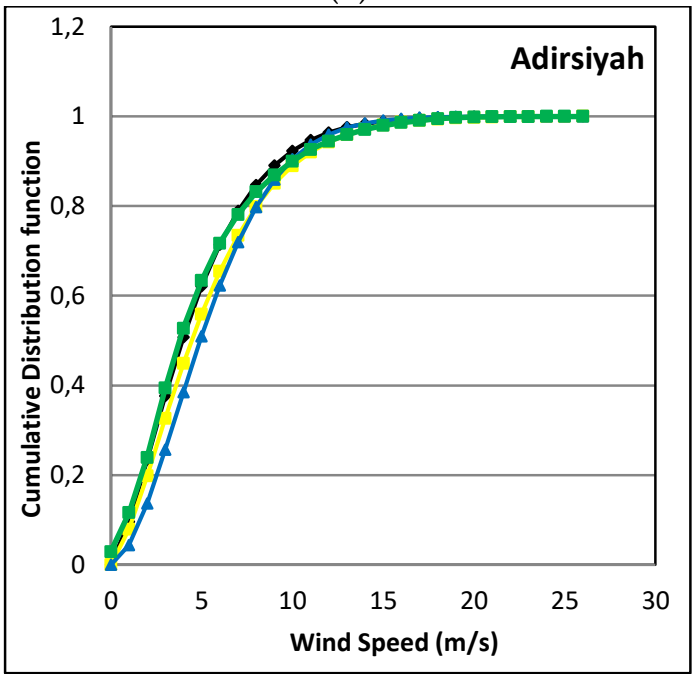

(d)

Figure 9. $(a, b, c, d)$ Cumulative distribution function for the sites at $60 \mathrm{~m}$ height.

When the curves given in Fig. 8(a, b, c, d) and Fig. 9(a, b, c, d) are examined, it is evaluated that all methods provided significantly close estimations with the actual data. The best estimate is feasible with GM. The errors associated with the different Weibull methods are calculated and shown in Tables 5 and 6. The closest values to zero for RMSE, MBE, and MAE verify that methods for calculating the Weibull parameters in this study are accurate and can be used for a wind energy assessment. Also, the $\mathrm{R}^{2}$ values are close to 1.0 for all the methods in all the sites which proves the accuracy of the used methods [21]. 
Table 5. Error analysis results $(20 \mathrm{~m})$.

\begin{tabular}{|c|c|c|c|c|c|}
\hline Sites & Method & $\mathrm{R}^{2}$ & RMSE & MBE & MAE \\
\hline \multirow{4}{*}{ Adirsiyah } & GM & $\mathbf{0 . 9 9 4 8}$ & $\mathbf{0 . 0 2 4 5}$ & $4.31 \mathrm{e}-05$ & $\mathbf{0 . 0 0 0 3 7}$ \\
\cline { 2 - 6 } & EMJ & 0.9947 & 0.0248 & $2.08 \mathrm{e}-05$ & 0.00039 \\
\cline { 2 - 6 } & MLM & 0.9855 & 0.0409 & $\mathbf{7 . 4 7 e - 0 6}$ & 0.00064 \\
\hline \multirow{4}{*}{ Elqatrun } & GM & 0.9696 & 0.0583 & $4.3 \mathrm{e}-05$ & 0.00080 \\
\cline { 2 - 6 } & EMJ & 0.9852 & 0.0406 & $2.53 \mathrm{e}-05$ & 0.00060 \\
\cline { 2 - 6 } & MLM & $\mathbf{0 . 9 8 9 9}$ & $\mathbf{0 . 0 3 3 5}$ & $\mathbf{1 . 7 3 e - 0 5}$ & $\mathbf{0 . 0 0 0 4 9}$ \\
\hline \multirow{4}{*}{ Mspiallata } & GM & $\mathbf{0 . 9 9 8 4}$ & $\mathbf{0 . 0 1 8 6}$ & $2.26 \mathrm{e}-06$ & $\mathbf{0 . 0 0 0 3 3}$ \\
\cline { 2 - 6 } & EMJ & 0.9972 & 0.0247 & $\mathbf{1 . 2 3 e - 6}$ & 0.00042 \\
\cline { 2 - 6 } & MLM & 0.9965 & 0.0278 & $2.52 \mathrm{e}-06$ & 0.00048 \\
\hline & GM & 0.9900 & 0.0379 & $2.26 \mathrm{e}-06$ & 0.00065 \\
\cline { 2 - 6 } & EMJ & $\mathbf{0 . 9 9 8 5}$ & $\mathbf{0 . 0 1 4 6}$ & $\mathbf{2 . 4 e - 0 7}$ & $\mathbf{0 . 0 0 0 2 2}$ \\
\cline { 2 - 6 } & MLM & 0.9947 & 0.0275 & $4.74 \mathrm{e}-07$ & 0.00048 \\
\hline \multirow{5}{*}{} & & & & &
\end{tabular}

Table 6. Error analysis results $(60 \mathrm{~m})$.

\begin{tabular}{|c|c|c|c|c|c|}
\hline Sites & Method & $\mathrm{R}^{2}$ & RMSE & MBE & MAE \\
\hline \multirow{4}{*}{ Adirsiyah } & GM & 0.9942 & 0.0259 & $6.57 \mathrm{e}-05$ & 0.00031 \\
\cline { 2 - 6 } & EMJ & $\mathbf{0 . 9 9 5 7}$ & $\mathbf{0 . 0 2 2 1}$ & $5.25 \mathrm{e}-05$ & $\mathbf{0 . 0 0 0 2 7}$ \\
\cline { 2 - 6 } & MLM & 0.9933 & 0.0277 & $\mathbf{2 . 0 7 e - 0 5}$ & 0.00041 \\
\hline \multirow{4}{*}{ Alqatrun } & GM & 0.9934 & 0.0270 & $1.22 \mathrm{e}-05$ & 0.00041 \\
\cline { 2 - 6 } & EMJ & 0.9968 & 0.0188 & $6.43 \mathrm{e}-06$ & 0.00028 \\
\cline { 2 - 6 } & MLM & $\mathbf{0 . 9 9 7 9}$ & $\mathbf{0 . 0 1 5 1}$ & $\mathbf{2 . 6 3 e - 0 6}$ & $\mathbf{0 . 0 0 0 2 4}$ \\
\hline \multirow{4}{*}{ Espiaa } & GM & 0.9977 & 0.0222 & $7.48 \mathrm{e}-06$ & 0.00033 \\
\cline { 2 - 6 } & EMJ & 0.9973 & 0.0241 & $1.51 \mathrm{e}-06$ & 0.00041 \\
\cline { 2 - 6 } & MLM & $\mathbf{0 . 9 9 8 8}$ & $\mathbf{0 . 0 1 6 3}$ & $\mathbf{1 . 2 1 e - 0 6}$ & $\mathbf{0 . 0 0 0 2 9}$ \\
\hline \multirow{3}{*}{ Msallata } & GM & 0.9981 & 0.0162 & $1.07 \mathrm{e}-06$ & 0.00023 \\
\cline { 2 - 6 } & EMJ & $\mathbf{0 . 9 9 8 6}$ & $\mathbf{0 . 0 1 4 2}$ & $5.88 \mathrm{e}-07$ & $\mathbf{0 . 0 0 0 1 9}$ \\
\cline { 2 - 6 } & MLM & 0.9978 & 0.0178 & $\mathbf{1 . 8 3 e - 0 7}$ & 0.00027 \\
\hline
\end{tabular}

As seen in Table 5, the best distribution performance was determined by GM at Adirsiyah and Espiaa for $20 \mathrm{~m}$ elevations. MLM results best fits for Alqatrun and EMJ results for Msallata concerning RMSE, MAE, MBE, and $\mathrm{R}^{2}$ criteria. The methods were evaluated for $60 \mathrm{~m}$ elevation and determined that EMJ gives better performance at Adirsiyah and Msallata as seen in Table 6. In Table 5, it can be seen that MLM at Alqatrun and Espiaa gives the best modeling performance. The lowest MBE value is determined with the MLM for Adirsiyah and Alqatrun, EMJ for Espiaa and Msallata at $20 \mathrm{~m}$ elevation. The lowest values for MAE were determined for Adirsiyah and Espiaa with GM, for Alqatrun with MLM, for 
Msallata with EMJ as seen in Table 5. By the assessment of data for $60 \mathrm{~m}$ elevation in Table 6, the lowest MBE values were obtained with MLM for four sites. The lowest MAE values were determined with MLM for Alqatrun and Espiaa and with EMJ for Adirsiyah and Msallata. Wind power density classifications are described in the literature as seen in Table 7 [45].

Table 7. Classification according to the wind power density [45].

\begin{tabular}{cccc}
\hline $\begin{array}{c}\text { Wind resource } \\
\text { category }\end{array}$ & Wind class & $\begin{array}{c}\text { Wind speed } \\
(\mathrm{m} / \mathrm{s})\end{array}$ & $\begin{array}{c}\text { Wind power } \\
\text { density }\left(\mathrm{W} / \mathrm{m}^{2}\right)\end{array}$ \\
\hline Poor & 1 & $3.5-5.6$ & $50-200$ \\
Marginal & 2 & $5.6-6.4$ & $200-300$ \\
Moderate & 3 & $6.4-7.0$ & $300-400$ \\
Good & 4 & $7.0-7.5$ & $400-500$ \\
Excellent & 5 & $7.5-8.0$ & $500-600$ \\
Excellent & 6 & $8.0-8.8$ & $600-800$ \\
Excellent & 7 & Above 8.8 & Above 800 \\
\hline
\end{tabular}

The estimated wind speed and wind power density for each site and the elevation with different Weibull methods are seen in Fig.10 and Fig. 11.

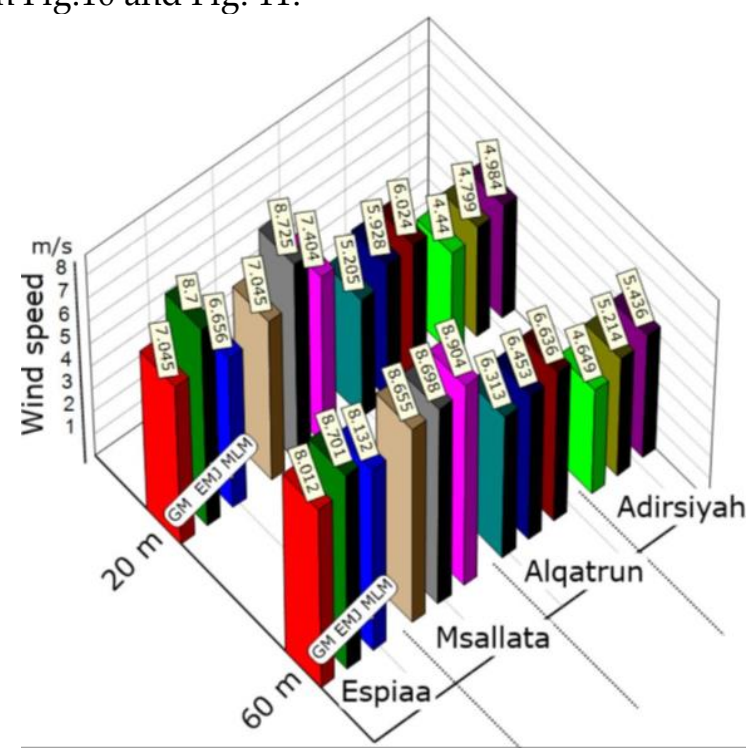

Figure 10. Wind speed at different elevations and locations due to the statistical approximation

The maximum wind speed of approximately $8.7 \mathrm{~m} / \mathrm{s}$ was determined with EMJ method at Espiaa as well as $20 \mathrm{~m}$ and $60 \mathrm{~m}$ elevation. The maximum wind speed of $8.725 \mathrm{~m} / \mathrm{s}$ at $20 \mathrm{~m}$ elevation and $8.698 \mathrm{~m} / \mathrm{s}$ at $60 \mathrm{~m}$ was determined with EMJ in Msallata. The power density of the wind is also illustrated in Fig. 11 , and it is seen that the power density at $20 \mathrm{~m}$ and $60 \mathrm{~m}$ elevation is $414.873 \mathrm{~W} / \mathrm{m}^{2}$ and $414.98 \mathrm{~W} / \mathrm{m}^{2}$ due to the EMJ. According to Table 7, Espiaa wind class 4 and category were evaluated as good. The highest wind power density state is in the Msallata and the wind power density $20 \mathrm{~m}$ and $60 \mathrm{~m}$ elevation was determined about $418.502 \mathrm{~W} / \mathrm{m}^{2}$ and $444.743 \mathrm{~W} / \mathrm{m}^{2}$ and for each elevation, the class of wind can be assessed as Class 4 and in the good category due to the Table 7. In Alqatrun and Adirsiyah the wind speed is seen lower than Espiaa and Msallata. The peak speed at Alqatrun is approximately $6.024 \mathrm{~m} / \mathrm{s}$ at $20 \mathrm{~m}$ elevation and $6.636 \mathrm{~m} / \mathrm{s}$ at $60 \mathrm{~m}$ elevation due to the MLM. In Adirsiyah, these speed values reach $4.984 \mathrm{~m} / \mathrm{s}$ and $5.436 \mathrm{~m} / \mathrm{s}$ in the same order. The wind power density values severely low at Alqatrun and Adirsiyah. The maximum wind power density was calculated as $137.736 \mathrm{~W} / \mathrm{m}^{2}$ and $184.134 \mathrm{~W} / \mathrm{m}^{2}$ at Alqatrun with MLM for $20 \mathrm{~m}$ and $60 \mathrm{~m}$ elevation. In Adirsiyah these values reach $77.993 \mathrm{~W} / \mathrm{m}^{2}$ and 
101.201 W/m². By the evaluation according to Table 7, the wind power density for $20 \mathrm{~m}$ and $60 \mathrm{~m}$ altitudes in both Alqatrun and Adirsiyah is below $200 \mathrm{~W} / \mathrm{m}^{2}$, and the wind class 1 and category were considered weak.

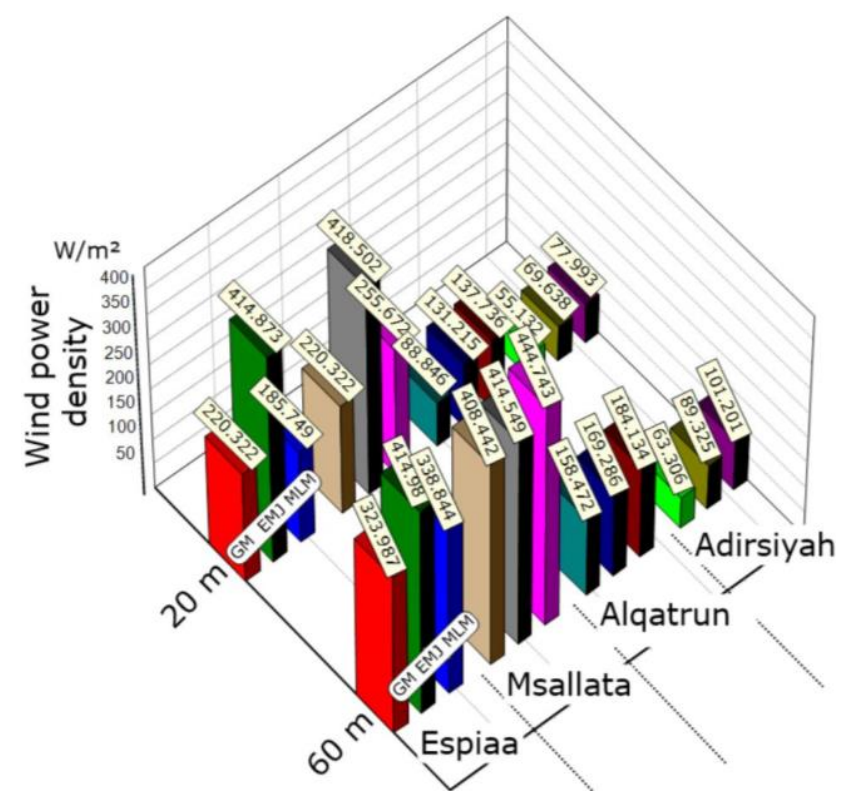

Figure 11. Wind power density at different elevations and locations due to the statistical approximation

\section{CONCLUSION}

Wind characteristics and wind energy potential of four sites of Libya are Espiaa, Msallata, Alqatrun, and Adirsiyah was assessed statistical Weibull distribution function methods that are GM, EMJ, and MLM. The resulting opinions can be summarized as follows.

- The wind speed distribution is determined by GM and MLM methods showed the best fit with the actual data.

- Statistical error distribution has best-fit performance was determined by GM at Adirsiyah and Espiaa for $20 \mathrm{~m}$ elevations. MLM results best fits for Alqatrun and EMJ results for Msallata concerning RMSE, MAE, MBE, and $\mathrm{R}^{2}$ criteria. For 60 m elevation EMJ gives the best modeling performance at Adirsiyah and Msallata and MLM at Alqatrun and Espiaa.

- The best wind power potential was determined at Espiaa with $414.98 \mathrm{~W} / \mathrm{m}^{2}$ power density at 60 $\mathrm{m}$ and Msallata with $444.743 \mathrm{~W} / \mathrm{m}^{2}$.

- The lowest wind power density was determined at Alqatrun and Adirsiyah with peak values of 184.134 W/m² and $101.201 \mathrm{~W} / \mathrm{m}^{2}$ for 60 m elevation.

- The wind power density of Espiaa is $414.873 \mathrm{~W} / \mathrm{m}^{2}$ and $418.502 \mathrm{~W} / \mathrm{m}^{2}$ at Msallata, $137.736 \mathrm{~W} / \mathrm{m}^{2}$ at Alqatrun, and $77.993 \mathrm{~W} / \mathrm{m}^{2}$ at Adirsiyah for $20 \mathrm{~m}$ elevations.

- The maximum wind power potential was determined at Msallata and the minimum at Adirsiyah.

- When the power density is evaluated, Msallata seems more feasible for wind farm investment compared to other states with a wind power density of $418,502 \mathrm{~W} / \mathrm{m}^{2}$ and $444.743 \mathrm{~W} / \mathrm{m}^{2}$ for $20 \mathrm{~m}$ and $60 \mathrm{~m}$ altitudes and the wind class is 4 and the category is good.

Future studies that are related to wind energy can investigate wind farm layout optimization, economic feasibility, and environmental impacts to develop wind farm projects. 


\section{REFERENCES}

[1] Ansari, M., 2018, "Libyan oil: Prospects for stability and growth", Apicorp Energy Research, Vol. 3, No. 14 , pp. 1-4.

[2] Morrow, S., "Blockade will halve Libya oil output: National Oil Co.", https://www.aa.com.tr/en/energy/oil/blockade-will-halve-libya-oil-output-national-oil-co/29834, access date: February 18, 2021.

[3] St John, R.B., 2008, "The changing Libyan economy: Causes and consequences", The Middle East Journal, Vol. 62, No. 1, pp. 75-91.

[4] Khalil, A., Asheibi, A., " The chances and challenges for renewable energy in Libya", 4th International Conference on Renewable Energy Research and Applications, Palermo, Italy, 1-6, November 22-25, 2015.

[5] Mrehel, O.G., Gerara Salama, A., "Energy generation potential from wind power in the Southern Libyan Regions", 2021 IEEE 1st International Maghreb Meeting of the Conference on Sciences and Techniques of Automatic Control and Computer Engineering MI-STA, 548-553, Tripoli, Libya, May 25-27, 2021.

[6] Elmnifi, M., Alshilmany, M., Abdraba, M., 2018, "Potential of municipal solid waste in Libya for energy utilization", Open Journal of Mechanical Engineering, Vol. 2, No. 1, pp. 1-5.

[7] Kutucu, H., Almryad, A., "Modeling of solar energy potential in Libya using an artificial neural network model", 2016 IEEE First International Conference on Data Stream Mining \& Processing (DSMP), 356-359, Lviv, Ukraine, August 23-27, 2016.

[8] Belgasim, B., Aldali, Y., Abdunnabi, M.J.R., Hashem, G., Hossin, K., 2018, "The potential of concentrating solar power (CSP) for electricity generation in Libya", Renewable and Sustainable Energy Reviews, Vol. 90, pp. 1-15.

[9] Mohamed, O.A., Masood, S.H., 2018, "A brief overview of solar and wind energy in libya: Current trends and the future development", IOP Conference Series: Materials Science and Engineering, Vol. 377, No. 1, 1-12.

[10] Nassar, Y.F., Salem, M.A., Iessa, K.R., AlShareef, I.M., Ali, K.A., Fakher, M.A., 2021, "Estimation of $\mathrm{CO}_{2}$ emission factor for the energy industry sector in libya: a case study", Environment, Development and Sustainability, doi: 10.1007/s10668-021-01248-9.

[11] Mohamed, A.M.A., Al-Habaibeh, A., Abdo, H., 2013, "An investigation into the current utilisation and prospective of renewable energy resources and technologies in Libya", Renewable Energy, Vol. 50, pp. 732-740.

[12] Mentis, D., Hermann, S., Howells, M., Welsch, M., Siyal, S.H., 2015, "Assessing the technical wind energy potential in Africa a GIS-based approach", Renewable Energy, Vol. 83, No. 7, pp. 110-125.

[13] El-Osta, W., Belhag, M., Klat, M., Fallah, I., Kalifa, Y., 1995, "Wind farm pilot project in Libya", Renewable Energy, Vol. 6, No. 5-6, pp. 639-642.

[14] Kassem, Y., Çamur, H., Aateg, R.A.F., 2020, "Exploring solar and wind energy as a power generation source for solving the electricity crisis in Libya", Energies, Vol. 13, No. 14, 3708.

[15] Schafer, I., "The renewable energy sector and youth employement in Algeria, Libya, Morocco and Tunisia", https://www.afdb.org/fileadmin/uploads/afdb/Documents/Publications/The_Renewable_Energy_S ector_and_Youth_Employment_in_Algeria_Libya_Morocco_and_Tunisia.pdf, access date: February 18, 2021.

[16] Elmabruk, A.M., Aleej, F.A., Badii, M.M., "Estimation of wind energy in Libya", 5th International Renewable Energy Congress (IREC), 1-6, Hammamet, Tunisia, March 25-27, 2014.

[17] Hasan, S.H.A., Guwaeder, A., Gao, W., 2017, "Wind energy assessment of the Zawiya Region, in northwest Libya", Energy and Power Engineering, Vol. 09, No. 06, pp. 325-331.

[18] Kassem, Y., Çamur, H., AbuGharara, M.A., 2019, "Assessment of wind energy potential for selecting small-scale wind turbines in low wind locations in Libya: A comparative study", International Journal of Engineering Research and Technology, Vol. 12, No. 6, pp. 820-836. 
[19] Elmabruk, A.M., "Estimation of wind energy and wind in some areas (second zone) in Libya", Ecologic Vehicles, Renewable Energies, 1-7, Monaco, French, March 26-29, 2009.

[20] Ali, H.M., Khamiss, R.E., Ahmed, M.Z., "Statistical study and evaluation of six numerical methodes to predict wind speed parameters of the Weibull function in Al- Aziziyah, Libya", 2021 IEEE 1st International Maghreb Meeting of the Conference on Sciences and Techniques of Automatic Control and Computer Engineering MI-STA, 463-467, Tripoli, Libya, May 25-27, 2021.

[21] Elfarra, M.A., Salem, S., 2018, "Technical and economical evaluation and GHG analysis of wind power generation in four sites using different Weibull parameters", International Journal of Renewable Energy Research, Vol. 8, No. 3, pp. 1-12.

[22] Katsigiannis, Y.A., Stavrakakis, G.S., Pharconides, C., 2013, "Effect of wind turbine classes on the electricity production of wind farms in Cyprus Island", Conference Papers in Energy, Vol. 2013, No. 5, pp. 1-6.

[23] Al-Nassar, W., Alhajraf, S., Al-Enizi, A., Al-Awadhi, L., 2005, "Potential wind power generation in the State of Kuwait", Renewable Energy, Vol. 30, No. 14, pp. 2149-2161.

[24] Mostafaeipour, A., Sedaghat, A., Dehghan-Niri, A.A., Kalantar, V., 2011, "Wind energy feasibility study for city of Shahrbabak in Iran", Renewable and Sustainable Energy Reviews, Vol. 15, No. 6, pp. 2545-2556.

[25] Ko, D.H., Jeong, S.T., Kim, Y.C., 2015, "Assessment of wind energy for small-scale wind power in Chuuk State, Micronesia", Renewable and Sustainable Energy Reviews, Vol. 52, No. 4, pp. 613-622.

[26] Irwanto, M., Gomesh, N., Mamat, M.R., Yusoff, Y.M., 2014, "Assessment of wind power generation potential in Perlis, Malaysia", Renewable and Sustainable Energy Reviews, Vol. 38, pp. 296-308.

[27] Ahwide, F., Spena, A., El-Kafrawy, A., 2013, "Estimation of electricity generation in libya using processing technology of wind available data: The case study in Derna", APCBEE Procedia, Vol. 5, No. 2-3, pp. 451-467.

[28] Kassem, Y., Gökcekus, H., Faraj, R.A., 2019, "Evaluation of the wind energy potential in Libya's Eastern Mediterranean Coast area using Weibull Distribution Function", International Journal of Applied Engineering Research, Vol. 14, No. 10, pp. 2483-2491.

[29] Artigao, E., Vigueras-Rodríguez, A., Honrubia-Escribano, A., Martín-Martínez, S., Gómez-Lázaro, E., 2021, "Wind resource and wind power generation assessment for education in engineering", Sustainability, Vol. 13, No. 5, 2444.

[30] Irwin, J.S., 1979, "A theoretical variation of the wind profile power-law exponent as a function of surface roughness and stability", Atmospheric Environment, Vol. 13, pp. 191-194.

[31] Chaurasiya, P.K., Ahmed, S., Warudkar, V., 2018, "Study of different parameters estimation methods of Weibull distribution to determine wind power density using ground-based Doppler SODAR instrument", Alexandria Engineering Journal, Vol. 57, No. 4, pp. 2299-2311.

[32] Aririguzo, J.C., Ekwe, E.B., 2019, "Weibull distribution analysis of wind energy prospect for Umudike, Nigeria for power generation", Robotics and Computer-Integrated Manufacturing, Vol. 55, pp. 160-163.

[33] Hulio, Z.H., Jiang, W., Rehman, S., 2019, "Techno - Economic assessment of wind power potential of Hawke's Bay using Weibull parameter: A review", Energy Strategy Reviews, Vol. 26, 100375.

[34] Saeed, M.A., Ahmed, Z., Yang, J., Zhang, W., 2020, "An optimal approach of wind power assessment using Chebyshev metric for determining the Weibull distribution parameters", Sustainable Energy Technologies and Assessments, Vol. 37, 100612.

[35] Fazelpour, F., Markarian, E., Soltani, N., 2017, "Wind energy potential and economic assessment of four locations in Sistan and Balouchestan province in Iran", Renewable Energy, Vol. 109, Part A, pp. 646-667.

[36] Kaoga, D.K., Danwe, R., Yamigno, S.D., Djongyang, N., 2015, "Performance analysis of methods for estimating Weibull Parameters for wind speed distribution in the district of Maroua", Journal of Fundamental and Applied Sciences, Vol. 6, No. 2, pp. 153-174. 
[37] Ouahabi, M.H., Elkhachine, H., Benabdelouahab, F., Khamlichi, A., 2020, "Comparative study of five different methods of adjustment by the Weibull model to determine the most accurate method of analyzing annual variations of wind energy in Tetouan - Morocco", Procedia Manufacturing, Vol. 46, pp. 698-707.

[38] Akdag, S.A., Dinler, A., 2009, "A new method to estimate Weibull parameters for wind energy applications", Energy Conversion and Management, Vol. 50, No. 7, pp. 1761-1766.

[39] Tiam Kapen, P., Jeutho Gouajio, M., Yemélé, D., 2020, "Analysis and efficient comparison of ten numerical methods in estimating Weibull parameters for wind energy potential: Application to the city of Bafoussam, Cameroon", Renewable Energy, Vol. 159, No. 2, pp. 1188-1198.

[40] Saeed, M.A., Ahmed, Z., Zhang, W., 2020, "Wind energy potential and economic analysis with a comparison of different methods for determining the optimal distribution parameters", Renewable Energy, Vol. 161, pp. 1092-1109.

[41] Wen, Y., Kamranzad, B., Lin, P., 2021, "Assessment of long-term offshore wind energy potential in the south and southeast coasts of China based on a 55-year dataset", Energy, Vol. 224, 120225.

[42] Cengel, Y.A., Boles, M.A., 2007, Thermodynamics: An engineering approach sixth ed., McGrawHill, Singapore.

[43] Oner, Y., Ozcira, S., Bekiroglu, N., Senol, I., 2013, "A comparative analysis of wind power density prediction methods for Çanakkale, Intepe region, Turkey", Renewable and Sustainable Energy Reviews, Vol. 23, No. 9, pp. 491-502.

[44] Kumar, K.S.P., Gaddada, S., 2015, "Statistical scrutiny of Weibull parameters for wind energy potential appraisal in the area of northern Ethiopia", Renewables: Wind, Water, and Solar, Vol. 2, No. 14, pp. 1-15.

[45] Ko, D.H., Jeong, S.T., Kang, K.S., 2015, "Assessment of offshore wind power potential in the western seas of Korea", Journal of Korean Society of Coastal and Ocean Engineers, Vol. 27, No. 4, pp. 266-273. 